Egyptian Journal of Rabbit Science, 28 (1): 195 -222(2018)

\title{
EFFECT OF EARLY DIETARY SUPPLEMENTATION OF PROBIOTIC AND FEED RESTRICTION POST WEANING ON PRODUCTIVE AND ECONOMICAL PERFORMANCE OF GROWING RABBITS
}

\author{
M.M. Beshara, A.M. Alazab, H.N. Fahim, A. El. M.I. El Desoky, M.A. Ragab, \\ A.M. El-Fhhat, and A.A. El-gamal \\ Anim. Prod. Res. Inst., Agric. Res. Center, Minis. of Agric. Dokki, Giza \\ Corresponding author: Malak Mansour: E-mail: malakman88@yahoo.com
}

\section{ABSTRACT:}

This study aims to present the different effects produced by a postweaning intake limitation strategy without or with early probiotic supplementation (Lacobacillus lactis $2.5 \times 10^{8} \mathrm{CUF}$, Bacillus subtilis 1.8 $x 10^{9} \mathrm{CUF} / \mathrm{g}$ ) from 3 to 12 weeks of age on growth performance, digestibility, viability, and economic efficiency of growing rabbits. A total number of 54 local growing Black Balady rabbits, divided into six dietary treatment groups three replicates each. The dietary levels of feed restriction $(F R)$ and probiotic $(P R)$ included $3 \times 2$ factorial design as follow: $T_{1}$ : Rabbits fed basal diet ad libitum,$T_{2}$ : Rabbits fed basal diet with early fed $0.4 \mathrm{~g}$ probiotic/ $\mathrm{kg}$ diet $(P R), T_{3}:$ Rabbits fed restricted by $120 \%$ from the energy requirements for maintenance $\left(F R_{120}\right), T_{4}$ : Rabbits fed restricted by $120 \%$ from the energy for maintenance with early fed $0.4 \mathrm{~g}$ probioticl $\mathrm{kg}$ diet, T5: Rabbits fed restricted by $140 \%$ of the energy requirements for maintenance $\left(F R_{140}\right)$ and $T_{6}:$ Rabbits fed restricted by $140 \%$ of the energy requirements for maintenance with early fed $0.4 \mathrm{~g}$ probiotic/ $\mathrm{kg}$ diet from 6 to 14 weeks of age.

The results showed that feeding probiotic (PR) early supplementation from 3 weeks of age to weaning (6 weeks of age) did not affect on body weight $(B W)$ and viability \% at weaning compared to the control groups.

Post weaning the rabbits fed ad libitum with early $P R 0.4 \mathrm{~g} / \mathrm{kg}$ diet at 3 weeks of age recorded significantly higher daily weight gain than control diet. Feed conversion was improved due to adding PR to the diet by about $10.8 \%$ compared to the control diet. Also, the Ad libitum diet with $P R$ resulted in increase the performance index.

The growing rabbits fed ad libitum had the highest daily weight gain compared to those fed restricted diet. The best value of feed conversion ratio $(F C R)$ achieved by fed sever feed restriction $\left(F R_{120}\right)$ and moderate 
feed restriction $\left(F R_{140}\right)$ compared to ad libitum diet. The $F R_{120}$ resulted in decrease all digestibility traits except for the digestibility of crude fiber compared to ad libitum feeding. The $F R_{140}$ did not cause any detrimental effect on digestibility of nutrients. Viability $\%$ was significantly improved by about $5.7 \%$ as a result of $F R_{120}$ compared to ad libitum group. The greatest value of economic efficiency produced by fed FR either $F R_{120}$ or $F R_{140}$.

Also all interaction treatments tend to significantly decrease daily feed intake and improve FCR except for the ad libitum with adding $P R$ and $F R_{120}$ without $P R$. The FR 120 with $P R$ and $F R_{140}$ with or without $P R$ increased PI. The ratio N/L increase significantly due to feeding on $F R_{120}$ with $P R$ early from 3 weeks of age compared to ad libitum feeding. Also, the most interaction dietary treatments improved V\%. All interaction treatments except for ad libitum with probiotic resulted in a significant higher economic efficiency than caused by feeding on ad libitum diet.

The current study illustrated that rabbit's start fed PR product early from 3 to 6 weeks of age pre weaning and feeding PR continued to 12 weeks of age with $F R_{120}$ post-weaning immediately or rabbits fed $F R_{140}$ with or without PR product showed be taken with considerable in the commercial exploitation of rabbits production for its high economically value, under the Egyptian environmental condition.

Key words: Rabbits, Feed restriction, Probiotic, Growth performance,

Nutrients, Digestibility

Weaning is a crucial period for all young animals is associated with a lot of stress and increased sensitivity to diseases (Kritas et al., 2008). Also, weaning is a stressful period related to large economic losses in rabbits husbandries. It can increase the susceptibility of animals to several infections. Thus, much attention has been drawn to different alternative strategies for prevention this problems. For example, post-weaning intake limitation strategies are now frequently employed in rabbit breeding systems to reduce the incidence of post-weaning digestive troubles and improve the feed efficiency, where, feed restriction in growing rabbits could be used with some advantages such as increase digestive efficiency, modifies the partition of body energy retention as protein instead of fat and it could reduce mortality and morbidity due to digestive troubles (Xiccato and Trocino, 2010). Also, the same authors added that from productive and economic points of view, feed 
rationing was more severe $(60-70 \%)$, mortality was significantly reduced with the minimum levels in growing rabbits. Generally, throughout the fattening period various restriction programs are possible: gradually declining or not, step by step, continuous or alternate restriction periods, etc. The restriction program must thus adapt to the objectives of the breeder, health status improvement, feed costs reduction or even reducing the pellet intake to encourage forage consumption (Yakubu et al., 2007).

Probiotics are defined as live microbial food ingredients that have a beneficial effect on health (Salminen et al., 1998). Probiotics have the ability to have a direct effect on pathogens by the production of an acidic environment, promoting the growth of a more beneficial microflora (Miettinen et al., 1996). Also, they enhance mucosal immunity of the host by eliciting production of immunoglobulin A as well as various cytokines (Isolauri et al., 2001). In addition, the beneficial effects of these microorganisms for their ability to modulate the intestinal micro flora have been postulated to include competition for substrate as well as competing for receptor sites at the mucosal surface (Vesterlund et al., 2006). Use of probiotics is considered to be an important approach for stimulation of growth and development of animals, including rabbits (Mayorova, 2007). Several studies have been shown the positive effect of probiotics on the control of certain pathogens in animals, where they appear to control enteric diseases associated with Escherichia coli or other enteric pathogens (Kritas et al., 2008). However, effects of probiotics depend on the microorganism species, their metabolic features, enzymatic activity, the nourishment regime of an animal, the composition and ratio of nutrients in a food, the structural features of the gastrointestinal tract, and its physiology.

For this reasons, the effects of feed restriction system with or without probiotic supplementation on the growth performance of growing rabbits were studied.

\section{MATERIALS AND METHODS}

This study was conducted at El-Serw Poultry Research Station, Animal Poultry Research Institute, Agriculture Research Center, Ministry of Agriculture, Egypt. Fifty four Black Balady rabbits 6 weeks of age were randomly assigned to one of six dietary experimental groups of (9 rabbits each) that was conducted from 6 to 12 weeks of age. At the onset of the experiment, rabbits were weighed and assigned to 6 treatments based on body weight so that mean body weight was similar for rabbits on all treatments and 
each treatment had three replicates (3 rabbits in each). The rabbits in each replicate were kept on in grower cages and fed their respective experimental diets (Table 1).

\section{The experimental diets:}

Initially, a total number of 10 Black Balady does during lactating wear randomly distributed individually into two experimental groups (5does/group), each group had nearly 27 growing rabbits weighing about $341.9 \mathrm{~g} /$ rabbit, the first group fed diets basal diet without probiotic product (PR) which contained Lacobacillus lactis $2.5 \times 10^{8} \mathrm{CUF}$, Bacillus subtilis $1.8 \times 10^{9} \mathrm{CUF} / \mathrm{g}$, the second group fed basal diet with $0.4 \mathrm{~g}$ PR/kg diet from 21 days to weaning at 6 weeks. Post weaning the same growing rabbits (54 unsexed weaned growing rabbits, weaning about $684 \mathrm{~g} /$ rabbit, divided into six dietary treatment groups' three replicates each. The dietary levels of feed restriction (FR) and probiotic product (PR) included $3 \times 2$ factorial design as follow: $\mathrm{T}_{1}$ : Rabbits fed basal diet ad libitum without supplemented probiotic, $\mathrm{T}_{2}$ : Rabbits fed basal diet ad libitum with early fed on $0.4 \mathrm{~g}$ PR / $\mathrm{kg}$ diet, $\mathrm{T}_{3}$ : Rabbits fed restricted system by $120 \%$ from the energy requirements for maintenance, $\mathrm{T}_{4}$ : Rabbits fed restricted system by $120 \%$ from the energy for maintenance with early fed on $0.4 \mathrm{~g}$ PR / kg diet, T5: Rabbits fed restricted system by $140 \%$ of the energy requirements for maintenance without supplemented probiotic and $\mathrm{T}_{6}$ : Rabbits fed restricted system by $140 \%$ of the energy requirements for maintenance with early fed on $0.4 \mathrm{~g}$ PR / $\mathrm{kg}$ diet.

The ingredients and the nutrient composition of the basal diet presented in Table (1), calculated analysis of basal diet according to feed composition Tables for rabbits feedstuffs used by Villamide et al., (2010), De Blas and Wiseman (2010) and NRC (1977) and the requirements of digestible energy (DE Kcal/kg diet) and crude protein \% according to FEDNA (2013). Saltose Ex is a thermo stable probiotic where each $1 \mathrm{~kg}$ contains lactic acid bacteria (Lacobacillus lactis) $2.5 \times 10^{8} \mathrm{CFU}$, Bacillus subtilis $1.8 \times 10^{9} \mathrm{CFU}$ and calcium carbonate up to 1 gram as carrier. This probiotic produced by Pic-Bio, Inc. Company- Japan. All rabbits were kept under the same managerial conditions.

The quantity of feed restriction given all at once and not several meals each day, where recently results illustrated that favorable effect of an intake limitation originates from the feed quantity itself and not from the feed distribution technique. The amount of feed allocated to restricted rabbits each distribution was calculated according to the live body weight and the energy requirements for maintenance $\left(430 \mathrm{Kj} \mathrm{DE} / \mathrm{d} / \mathrm{kg} \mathrm{LW}^{0.75}\right.$ ) according to Xiccato 
Table (1): Composition and calculated analysis of the basal diet

\begin{tabular}{|l|c|}
\hline \multicolumn{1}{|c|}{ Ingredients } & \% \\
\hline Barley grain & 24.60 \\
Alfalfa hay & 31.00 \\
Soy bean meal $(44 \%)$ & 13.25 \\
Wheat brain & 28.00 \\
Di-calcium phosphate & 1.60 \\
Limestone & 0.95 \\
Sodium chloride & 0.30 \\
Mineral-vitamin premix ${ }^{1}$ & 0.30 \\
Total & 100 \\
\hline Calculated Analysis ${ }^{2}$ & \\
\hline Crude protein \% & 17.08 \\
DE (Kcal / kg) & 2416 \\
Crude fiber \% & 12.55 \\
Ether extract \% & 2.20 \\
Calcium \% & 1.20 \\
T. Phosphorus \% & 0.76 \\
Lysine $(\%)$ & 0.84 \\
Methionine $(\%)$ & 0.23 \\
Lysine (\%) & 0.86 \\
Price (LE/kg) ${ }^{4}$ & 4.68 \\
\hline
\end{tabular}

(1) One kilogram of mineral-vitamin premix provided: Vitamin A, 150,000 UI; Vitamin E, 100 mg; Vitamin K3, 21mg; Vitamin B1, 10 mg; VitaminB2, 40mg; Vitamin B6, 15mg; Pantothenic acid, $100 \mathrm{mg}$; Vitamin B12, 0.1 mg; Niacin, $200 \mathrm{mg}$; Folic acid, 10mg; Biotin, $0.5 \mathrm{mg}$; Choline chloride, 5000 mg; Fe, 0.3mg; Mn, 600 mg; Cu, 50 mg; Co, 2 mg; Se, 1mg; and Zn, 450mg.

(2) Calculated analysis according to feed composition tables for rabbits feedstuffs used by De Blas and Mateos (2010); ME (Kcal/kg diet) estimated as 0.95 DE according to Santoma et al. (1989)

${ }^{(4)}$ Price of one $\mathrm{kg}$ (Egyptian pound/Kg) for different ingredients: Barley grain, 4.6.; Alfalfa hay, 2.8.; Soy been meal, 8.0.; Wheat bran, 2.1.; Di-calcium, 10.8; limestone, 0.20; Premix, 60.0; Sodium chloride, 0.50 and $\mathrm{Kg}$ of Probiotics, 200 (LE)

and Trocino (2010) then convert the energy from Kcal $/ \mathrm{kg}$ diet to grams/day afterward addition 20 and $40 \%$ on the energy requirements for maintenance.

\section{Growth performance traits:}

Live body weight, daily feed intake and number of dead rabbits were recorded. Daily weight gain, feed conversion ratio was determined every week and mortality rate were estimated daily. The performance index (PI, \%) was calculated according to North (1981) on a group basis:

$\mathrm{PI}(\%)=($ Final live body weight $(\mathrm{kg}) /$ Feed conversion at any period studied $\mathrm{x} 100$ 


\section{Digestibility trail}

A digestibility trail was performed on eighteen male rabbits, to determine the apparent nutrient digestibility of the six experimental diets (3 males in each treatment group). Animals were housed in metabolic cages that allowed separation of faeces and urine. Faeces produced daily were collected in polyethylene bags for three consecutive days. Chemical analysis was carried out for hard faeces according to A.O.A.C. (2005) for ash, dry matter (DM), crude protein $(\mathrm{CP})$, crude fiber $(\mathrm{CF})$ and ether extract $(\mathrm{EE})$.

\section{Serum biochemical parameters and Hematological:}

At the end of study (14 weeks of age), three rabbits ( 3 males in each treatment group) were taken randomly from each treatment, fasted for $12 \mathrm{hrs,}$ weighed and slaughtered to estimate some of carcass traits. Carcass parts were presented as a percent of preslaughter live body weight which included carcass, giblets, kidney, heart, liver, abdominal fat, gastrointestinal tract and cecum\%. Blood samples were collected without anticoagulant and kept at room temperature then the tubes were centrifuged at $3500 \mathrm{rpm}$ for 20 minutes to separate clear serum, afterward blood serum was used to determine serum total protein, triglycerides, total cholesterol and liver enzymes activities by using commercial kits. Another blood samples were taken in vial tubes containing anticoagulant from three rabbits per treatment to determine some hematological traits which included red blood cells $\left(\mathrm{RBC} \times 10^{12}\right)$, hematocrit (HCT \%), hemoglobin (HEB (g/dl), white blood cells (WBC x109), lymphocyte (L\%) neutrophil (N\%), neutrophil/lymphocyte (N/L), monocyte (M\%) and eosinophil (E\%).

\section{Economic efficiency:}

At the end of the study, economical efficiency for weight gain was expressed as rabbit-production thought the study and calculated using the following equation:

Economic efficiency $(\%)=($ Net return LE/ Total feed cost LE $) \times 100$. Where Net return $=$ Total return- Cost of feeding

\section{Statistical analysis:}

Data were statistically analyzed using General Linear Models Procedure of the SPSS program (2008), A factorial design 3x2 was used; the following model was used to study the effect of main factors and interaction between feed restriction (FR) and probiotics (PR) on parameters investigated according to Snedecor and Cochran (1982) as follows: 


$$
\mathrm{Y}_{\mathrm{ijk}}=\mu+\mathrm{T}_{\mathrm{i}}+\mathrm{R}_{\mathrm{j}}+(\mathrm{TR})_{\mathrm{ij}}+\mathrm{e}_{\mathrm{ijk}}
$$

Where : $Y_{\mathrm{ijk}}=$ An observation; $\mu=$ Overall mean ; $T_{i}=$ Effect of FR level( $\mathrm{i}=1$, 2 and 3$) ; R_{j}=$ effect of PR level $\left(j=(1\right.$ and 2$) ;(T R)_{i j}=$ Effect of interaction between FR and PR (ij = 1, 2...6); and $\mathrm{e}_{\mathrm{jik}}=$ Experimental error.

Differences means among treatments were subjected to Duncan's Multiple Range- test (Duncan, 1955).

\section{RESULTS AND DISCUSSION}

\section{Growth performance}

The results showed that feeding probiotics early from 3 weeks preweaning to weaning at 6 weeks of age did not effect on body weight (BW) and viability at weaning as compared to the control groups (Data not show). The effect of feed restriction (FR), dietary early probiotics at 3 weeks of age before weaning (EPR) and the interaction between them on BW and weight gain (WG) is showed in Table 2. The results of the current study did not observe any significant differences in BW at 6 and 8 weeks of age due to applied strategy of strong FR (120\% from the energy requirements for maintenance) $\left(\mathrm{FR}_{120}\right)$ or moderate $\mathrm{FR}$ (140\% from the energy requirements for maintenance) $\left(\mathrm{FR}_{140}\right)$. However, at 10 and 12 weeks of age the statistical analysis revealed that FR at $120 \%$ of energy requirement for maintenance $\left(\mathrm{FR}_{120}\right)$ significantly decreased BW compared to ad libitum diet.

Regarding daily WG, the results showed that the dietary FR had no significant effect on daily WG of grower rabbits during the periods 6 and 8 weeks of age as compared to the control diet, but afterward it is clearly observed that grower rabbits received ad libitum feeding always had the highest daily WG records through the interval periods (8-10 and 10-12) and during the whole experimental period from 6 to 12 weeks of age as compared to the restricted diet.

In addition, the results illustrated that grower rabbits fed early PR by $0.4 \mathrm{~g} /$ $\mathrm{kg}$ diet at 3 weeks of age recorded significantly higher BW and WG than control diet during all periods of the study.

Results concerning BW and daily WG as influenced by the interaction between FR and PR showed that rabbits fed ad libitum diet with 0.4g EPR product $/ \mathrm{kg}$ diet resulted in a significant increase in BW at 8 weeks of age compared to those on restricted feeding system up to $120 \%$ of energy for maintenance at 8 weeks of age, and nearly the same manner, BW was 
Table (2): Effect of feed restriction system, probiotics product and their interaction between them on bogy weight and daily weight of grower rabbits from 6 to 12 weeks of age

\begin{tabular}{|c|c|c|c|c|c|c|c|c|c|}
\hline \multirow{2}{*}{\multicolumn{2}{|c|}{$\begin{array}{l}\text { Traits } \\
\text { Factors }\end{array}$}} & \multicolumn{4}{|c|}{ Body weight (g/rabbit),weeks } & \multicolumn{4}{|c|}{ Daily weight gain (g/rabbit/day) } \\
\hline & & 6 & $8 \mid$ & 10 & 12 & $6-8$ & $8--10$ & $10-12$ & 6-12 \\
\hline \multicolumn{10}{|c|}{ Feed restriction system $(F R)$} \\
\hline \multicolumn{2}{|c|}{ Ad-lib $^{1}$} & 685.0 & 1108.0 & $1416.4^{\mathrm{a}}$ & $1849.8^{\mathrm{a}}$ & 30.2 & $22.0 \mathrm{a}$ & $22.9 \mathrm{a}$ & $25.0 \mathrm{a}$ \\
\hline \multicolumn{2}{|c|}{$120 \%^{2}$} & 683.8 & 1029.1 & $1243.7^{\mathrm{b}}$ & $1572.7^{\mathrm{b}}$ & 24.7 & $15.0 \mathrm{c}$ & $17.3 b$ & $19.0 \mathrm{c}$ \\
\hline \multicolumn{2}{|c|}{$140 \%^{3}$} & 685.3 & 1061.5 & $1319.5^{\mathrm{ab}}$ & $1731.0^{\mathrm{a}}$ & 26.7 & $18.0 \mathrm{~b}$ & $22.3 \mathrm{a}$ & $22.4 \mathrm{~b}$ \\
\hline \multicolumn{2}{|c|}{$\pm \mathrm{SE}$} & 15.04 & 28.43 & 36.54 & 47.44 & 1.74 & 0.93 & 0.65 & 0.74 \\
\hline \multicolumn{2}{|l|}{ Sig. } & NS & NS & 0.05 & 0.05 & NS & 0.05 & 0.05 & 0.05 \\
\hline \multicolumn{10}{|c|}{ Probiotic product $(P R)$} \\
\hline \multicolumn{2}{|l|}{$(0)^{4}$} & 686.3 & $1057.9^{\mathrm{b}}$ & $1313.5^{\mathrm{b}}$ & $1684.2^{\mathrm{b}}$ & $26.3^{\mathrm{b}}$ & $18.1^{\mathrm{b}}$ & $18.8^{\mathrm{b}}$ & $21.1^{\mathrm{b}}$ \\
\hline \multicolumn{2}{|l|}{$0.4 \mathrm{~g}^{5}$} & 683.3 & $1074.5^{\mathrm{a}}$ & $1339.5^{\mathrm{a}}$ & $1751.4^{\mathrm{a}}$ & $28.0^{\mathrm{a}}$ & $18.6^{\mathrm{a}}$ & $22.9^{\mathrm{a}}$ & $23.1^{\mathrm{a}}$ \\
\hline \multicolumn{2}{|l|}{$\pm \mathrm{SE}$} & 12.29 & 23.2 & 29.8 & 38.74 & 1.42 & 0.76 & 0.53 & 0.61 \\
\hline \multicolumn{2}{|l|}{ Sig. } & NS & 0.05 & 0.05 & 0.05 & 0.05 & 0.05 & 0.05 & 0.05 \\
\hline \multicolumn{10}{|c|}{ Interaction effect (FR $x P R)$} \\
\hline \multirow{2}{*}{ Ad-lib } & 0 & 686.7 & $1063.3^{\mathrm{ab}}$ & $1367.2^{\mathrm{ab}}$ & $1765.8^{\mathrm{ab}}$ & $26.7^{\mathrm{ab}}$ & $21.8^{\mathrm{a}}$ & $19.2^{\mathrm{cd}}$ & $22.6^{\mathrm{b}}$ \\
\hline & 0.4 & 683.3 & $1152.6^{\mathrm{a}}$ & $1465.7^{\mathrm{a}}$ & $1933.7^{\mathrm{a}}$ & $33.7^{\mathrm{a}}$ & $22.1^{\mathrm{a}}$ & $26.7^{\mathrm{a}}$ & $27.4^{\mathrm{a}}$ \\
\hline \multirow{2}{*}{$120 \%$} & 0 & 684.3 & $1011.4^{\mathrm{b}}$ & $1237.0^{\mathrm{b}}$ & $1579.3^{\mathrm{b}}$ & $23.3^{\mathrm{b}}$ & $15.8^{\mathrm{bc}}$ & $16.4^{\mathrm{d}}$ & $18.5^{\mathrm{c}}$ \\
\hline & 0.4 & 683.3 & $1046.8^{\mathrm{ab}}$ & $1250.4^{\mathrm{b}}$ & $1566.1^{\mathrm{b}}$ & $26.0^{\mathrm{ab}}$ & $14.3^{\mathrm{a}}$ & $18.1^{\text {cd }}$ & $19.5^{\mathrm{bc}}$ \\
\hline \multirow[b]{2}{*}{$140 \%$} & 0 & 687.7 & $1098.9^{\mathrm{ab}}$ & $1336.4^{\mathrm{ab}}$ & $1707.6^{\mathrm{b}}$ & $29.0^{\mathrm{ab}}$ & $16.6^{\mathrm{bc}}$ & $20.8^{\mathrm{ab}}$ & $22.3^{\mathrm{b}}$ \\
\hline & 0.4 & 683.0 & $1024.2^{\mathrm{ab}}$ & $1302.5^{\mathrm{ab}}$ & $1754.4^{\mathrm{ab}}$ & $24.3^{\mathrm{b}}$ & $19.3^{\mathrm{ab}}$ & $23.8^{\mathrm{b}}$ & $22.5^{\mathrm{b}}$ \\
\hline \multicolumn{2}{|c|}{$\pm \mathrm{SE}$} & 21.28 & 40.2 & 51.67 & 67.09 & 2.47 & 1.32 & 0.91 & 1.05 \\
\hline \multicolumn{2}{|c|}{ Sig. } & NS & 0.05 & 0.05 & 0.05 & 0.05 & 0.05 & 0.05 & 0.05 \\
\hline
\end{tabular}

${ }^{1}$ The basal diet, which without probiotic and fed ad-lib; ${ }^{2}$ the basal diet fed $120 \%$ of the energy for maintenance regardless the supplementation of the probiotic; ${ }^{3}$ the basal diet fed $140 \%$ of the energy for maintenance regardless the supplementation of the probiotic; ${ }^{4}$ fed the basal diets without probiotic regardless feed restriction; ${ }^{5}$ fed the basal diet with $0.04 \mathrm{~g}$ probiotic/Kg diet regardless feed restriction. $\mathrm{a}, \mathrm{b}, \mathrm{c}$ :means in the same column bearing different superscripts are significantly different $(\mathrm{P} \leq 0.05)$. NS $=$ Non-significant

significantly increased by ad libitum diet with adding $0.4 \mathrm{~g}$ EPR $/ \mathrm{kg}$ diet compared to restricted feeding up to $120 \%$ with or without PR and $140 \%$ of energy for maintenance without PR. As for daily WG, it could be concluded that irrespective of the fluctuations observed during the interval periods, the daily WG as a result from ad libitum feeding with adding $0.4 \mathrm{~g} \mathrm{PR} / \mathrm{kg}$ diet was significantly better than daily WG from control and other interaction 
treatments, but it is interesting to note that the lowest value was attained from restricted feeding up to $\mathrm{FR}_{120}$ by about $18.14 \%$ compared to ad libitum group. On the other hand, the other dietary interaction treatments had no significant impact on the daily WG comparing with ad libitum diet.

The mean values for daily feed intake (FI) (g/rabbit/day) and feed conversion ratio (FCR) are given in Table 3. It is evident that the two levels of FR (severe and moderate levels) resulted in a significant decrease in daily FI during interval and collective periods where rabbits fed $120 \%$ of energy requirements for maintenance recorded $53 \mathrm{~g} /$ day/rabbit followed by those fed $\mathrm{FR}_{140}$ (63.9 g/ day/ rabbit) while the rabbits fed Ad-libitum recorded 89.2 $\mathrm{g} /$ day/rabbit. In respect of FCR, it is logically to find that the best value was to rabbits fed $\mathrm{FR}_{120}$ and $\mathrm{FR}_{140}$ where FCR related to $\mathrm{FI}$ and daily weight gain.

No significant influence of dietary probiotic on FI, however, the FCR was improved due to adding the probiotic to the diet $(0.4 \mathrm{~g} / \mathrm{kg}$ diet $)$ by about $10.8 \%$ compared to the control diet.

As for the interaction between FR and PR, the results showed that all interaction treatments tend to significantly decrease daily FI and improve the ratio of FCR except for the ad libitum with adding $0.4 \mathrm{~g}$ probiotic/ $\mathrm{kg}$ diet and $120 \%$ FR without PR as compared to control group.

Regarding the effect of FR, it is interesting to note that the growth reduction was 14.98 and $6.62 \%$ to $\mathrm{FR}_{120}$ and $\mathrm{FR}_{140}$ (severe and moderate FR respectively) as compared to the ad libitum diet. While, the intake reduction was 40.5 for strong FR and $28.36 \%$ for moderate FR thus it is logically to found that FCR significantly improved by FR. These results are consist with Gidenne and Feugier, (2009) who mentioned that daily weight gain decrease by increasing intensity of feed restriction (90, 80, 70 or $60 \%$ of Ad-libitum). Also, Tumova et al. (2002) reported that feed efficiency improve by restricted feeding. The beneficial effect of FR on FCR may be explained as follow: 1) Feed restriction sometimes decreases the incidence of post-weaning digestive disorders (Di Meo et al., 2007). 2) A moderate feed restriction system had some advantages in growing rabbits such as increase digestive efficiency, modifies the partition of body energy retention as protein instead of fat and it could reduce mortality and morbidity due to digestive troubles (Xiccato and Trocino 2010). The FCR improvement was observed irrespective of the diet's composition (Gidenne and Lebas, 2006).

Scientific publication stated that dietary adding of probiotics (PR) caused to improve growth rate and enhanced efficiency of feed conversion (Amber et al., 2004). Also, Karitas et al. (2008) observed that administration of PR BioPlus at $400 \mathrm{~g} / \mathrm{ton}$ of feed growing rabbits starting 4 days post weaning up to 5 
Table (3): Effect of feed restriction system, probiotics product and their interaction between them on feed intake and feed conversion ratio of grower rabbits from 6 to 12 weeks of age

\begin{tabular}{|c|c|c|c|c|c|c|c|c|c|}
\hline \multirow{2}{*}{\multicolumn{2}{|c|}{$\begin{array}{l}\text { Traits } \\
\text { Factors }\end{array}$}} & \multicolumn{4}{|c|}{ Feed intake (g)/rabbit/day } & \multicolumn{4}{|c|}{ Feed conversion ratio } \\
\hline & & $6-8$ & 8-10 & $10-12$ & 6-12 & 6-8 & 8--10 & 10-12 & 6-12 \\
\hline \multicolumn{10}{|c|}{ Feed restriction system (FR) } \\
\hline \multicolumn{2}{|c|}{$A d-l i b^{l}$} & $67.5^{\mathrm{a}}$ & $89.3^{\mathrm{a}}$ & $110.9^{\mathrm{a}}$ & $89.2^{\mathrm{a}}$ & $2.7^{\mathrm{a}}$ & 4.1 & $5.1^{\mathrm{a}}$ & $3.9^{\mathrm{a}}$ \\
\hline \multicolumn{2}{|c|}{$120 \%^{2}$} & $42.0^{\mathrm{c}}$ & $53.7^{\mathrm{c}}$ & $63.0^{\mathrm{c}}$ & $53.0^{\mathrm{c}}$ & $2.0^{\mathrm{b}}$ & 3.7 & $4.0^{\mathrm{b}}$ & $3.2^{\mathrm{b}}$ \\
\hline \multicolumn{2}{|c|}{$140 \%^{3}$} & $50.3^{\mathrm{b}}$ & $64.2^{\mathrm{b}}$ & $77.5^{\mathrm{b}}$ & $63.9^{\mathrm{b}}$ & $2.2^{\mathrm{ab}}$ & 3.8 & $3.8^{\mathrm{b}}$ & $3.2^{\mathrm{b}}$ \\
\hline \multicolumn{2}{|c|}{ \pm SE mean } & 0.91 & 1.50 & 1.40 & 1.17 & 0.19 & 0.16 & 0.15 & 0.07 \\
\hline \multicolumn{2}{|l|}{ Sig. } & 0.05 & 0.05 & 0.05 & 0.05 & 0.05 & NS & 0.05 & 0.05 \\
\hline \multicolumn{10}{|c|}{ Probiotics product $(P R)$} \\
\hline \multicolumn{2}{|c|}{$(0)^{4}$} & 52.4 & 69.4 & 84.0 & $68.6^{\mathrm{b}}$ & 2.4 & 3.9 & $4.8^{\mathrm{a}}$ & $3.7^{\mathrm{a}}$ \\
\hline \multicolumn{2}{|l|}{$0.4 \mathrm{~g}^{5}$} & 54.1 & 68.7 & 83.6 & $68.8^{\mathrm{a}}$ & 2.1 & 3.9 & $3.8^{\mathrm{b}}$ & $3.3^{\mathrm{b}}$ \\
\hline \multicolumn{2}{|l|}{$\pm \mathrm{SE}$} & 0.75 & 2.22 & 1.14 & 0.95 & 0.16 & 0.13 & 0.12 & 0.06 \\
\hline \multicolumn{2}{|l|}{ Sig. } & NS & NS & NS & 0.05 & NS & NS & 0.05 & 0.05 \\
\hline \multicolumn{10}{|c|}{ Interaction effect (FR $x$ PR $)$} \\
\hline \multirow{2}{*}{ Ad-lib } & 0 & $65.0^{\mathrm{b}}$ & $89.3^{\mathrm{a}}$ & $111.2^{\mathrm{a}}$ & $88.5^{\mathrm{a}}$ & $3.0^{\mathrm{a}}$ & $4.1 \mathrm{ab}$ & $5.9 \mathrm{a}$ & $4.3^{\mathrm{b}}$ \\
\hline & 0.4 & $70.0 \mathrm{a}$ & $89.2^{\mathrm{a}}$ & $110.5^{\mathrm{a}}$ & $90.0^{\mathrm{a}}$ & $2.3^{\mathrm{a}}$ & $4.1 \mathrm{ab}$ & $4.3^{\mathrm{bcd}}$ & $3.5^{\mathrm{ab}}$ \\
\hline \multirow{2}{*}{$120 \%$} & 0 & $41.7^{\mathrm{d}}$ & $53.1^{\mathrm{c}}$ & $63.0^{\mathrm{c}}$ & $52.7^{\mathrm{c}}$ & $2.3^{\mathrm{a}}$ & $3.5 b$ & $4.4 b$ & $3.4^{\mathrm{bc}}$ \\
\hline & 0.4 & $42.7^{d}$ & $54.3^{\mathrm{c}}$ & $63.1^{\mathrm{c}}$ & $53.2^{\mathrm{c}}$ & $1.7^{\mathrm{b}}$ & $4.3 \mathrm{a}$ & $3.6^{\mathrm{cd}}$ & $3.1^{\mathrm{c}}$ \\
\hline \multirow{2}{*}{$140 \%$} & 0 & $50.7^{\mathrm{c}}$ & $65.9^{\mathrm{b}}$ & $77.8^{\mathrm{b}}$ & $64.7^{b}$ & $2.0^{\mathrm{b}}$ & $4.0 \mathrm{ab}$ & $4.1 \mathrm{bc}$ & $3.3^{\mathrm{c}}$ \\
\hline & 0.4 & $50.0^{\mathrm{c}}$ & $62.5^{b}$ & $77.2^{\mathrm{b}}$ & $63.2^{\mathrm{b}}$ & $2.3^{\mathrm{a}}$ & $3.5 \mathrm{ab}$ & $3.5 \mathrm{~d}$ & $3.1^{\mathrm{c}}$ \\
\hline \multicolumn{2}{|c|}{ \pm SE mean } & 1.29 & 1.11 & 1.98 & 1.65 & 0.27 & 0.23 & 0.21 & 0.10 \\
\hline \multicolumn{2}{|c|}{ Sig. } & 0.05 & 0.05 & 0.05 & 0.05 & 0.05 & 0.05 & 0.05 & 0.05 \\
\hline
\end{tabular}

a, b, c, d, e: means in the same column bearing different superscripts are significantly different $(\mathrm{P} \leq 0.05) . \mathrm{NS}=$ Non-significant

days prior the slaughter age significantly improves body weight and daily weight gain. At sight on results (Oso et al., 2013) it is illustrated that the highest feed FCR was obtained with growing rabbits fed diets containing Bacillus cereus ( $1 \times 10^{9} \mathrm{cfu} / \mathrm{g}: 0.05 \mathrm{~g} / \mathrm{kg}$ ) as compared to the ad libitum diet. In addition, Amber et al., (2014) found that rabbits fed with supplementing BioMos (prebiotic), Bio-Plus (probiotic) or their mix of early period (at 3 weeks of age) in diets increased feed intake; also who illustrated that rabbits start fed PR early from 3 to 13 weeks of age improved relative growth by $3.13 \%$ as compared with those start fed PR later from 5 to 13 weeks of age. The 
beneficial effect of PR inclusion in the diet is speculative; it may be attributed to probiotics can alter the physical microenvironment of the intestinal tract in such a manner that opportunistic pathogens cannot survive (Chichlowski et al., 2007). In addition, probiotic can improve the condition of digestive canal that is short of digestive enzymes (Wang et al., 2008). Also, probiotic may improve weight gain due to better utilization of feed and larger absorption surface in the gut and also may positively influence the health status via enhancing the gut health in rabbits (Pogány et al., 2015).

\section{Performance index and viability:}

Generally, irrespective of the fluctuations observed during the interval periods, performance index (PI) was not significantly affected by dietary FR compared to ad libitum feeding (Table 4 ). While, viability $\%$ was significantly improved by about $5.7 \%$ as a result of $\mathrm{FR}_{120}$ compared to ad libitum group. In respect of cecum microbial activity, the results indicated that total bacterial count (TBC) was significantly increased due to FR by 120 and $140 \%$ of energy for maintenance while, $\mathrm{FR}_{120}$ resulted in a significant increase in lactic acid bacteria (LAB) compared to ad libitum feeding. On the other hand, the ratio $\mathrm{LAB} / \mathrm{TBC}$ was significantly lower as a result from $\mathrm{FR}_{140}$ than ad libitum diet.

Regarding dietary probiotics, no significant influence of dietary PR on total PI and V\% could be detected. Results showed that rabbits start fed experimental probiotic early from 3 weeks of age before weaning had significantly higher TBC while no significant effect on LAB and the same treatment had significantly lower LAB/TBC than those fed the control diet.

All rabbits fed dietary probiotics early with FR at 6 weeks of age resulted in a significant improve in total PI compared to control diet. Also, viability \% of rabbits fed all dietary interaction treatments except for those fed $\mathrm{FR}_{140}$ with PR was significantly higher than the values recorded by control diet.

These results showed that FR system improved viability \%, several studies were published recently to analyze the different effects of FR on the growth, digestive physiology and health of the young rabbit. For example, Di Meo et al. (2007) reported that FR sometimes decreases the incidence of post-weaning digestive disorders. In addition, a moderate feed restriction in growing rabbits could be used with some advantages such as increase digestive efficiency, modifies the partition of body energy retention as protein instead of fat and it could reduce mortality and morbidity due to digestive troubles (Xiccato and Trocino 2010). While, some studies referred to FR did not effect on mortality in growing rabbits post weaning (Gidenne et al., 2009). 
Table (4): Effect of feed restriction system, probiotics product and their interaction between them on performance index, viability and microbial activity of grower rabbits

\begin{tabular}{|c|c|c|c|c|c|c|}
\hline \multirow{2}{*}{\multicolumn{2}{|c|}{ Factors }} & \multicolumn{3}{|c|}{$\mathbf{P I}^{1}$} & \multirow[t]{2}{*}{ T.PI } & \multirow[t]{2}{*}{$\mathbf{V}^{2}$} \\
\hline & & 8 & 10 & 12 & & \\
\hline \multicolumn{7}{|c|}{ Feed restriction system (FR) } \\
\hline \multirow{5}{*}{\multicolumn{2}{|c|}{$\begin{array}{c}\text { Ad-lib } \\
120 \% \\
140 \% \\
\text { +SE mean } \\
\quad \text { Sig. }\end{array}$}} & 36.4 & $32.9^{\mathrm{b}}$ & $33.1^{b}$ & 47.9 & $92.6^{b}$ \\
\hline & & 46.6 & $38.6^{\mathrm{ab}}$ & $32.4^{\mathrm{b}}$ & 48.9 & $98.2^{\mathrm{a}}$ \\
\hline & & 43.0 & $42.6^{\mathrm{a}}$ & $35.6^{\mathrm{a}}$ & 54.4 & $94.4^{\mathrm{ab}}$ \\
\hline & & 3.50 & 2.73 & 0.82 & 2.01 & 1.51 \\
\hline & & NS & 0.05 & 0.05 & NS & 0.05 \\
\hline \multicolumn{7}{|c|}{ Probiotics product $(P R)$} \\
\hline \multirow{4}{*}{\multicolumn{2}{|c|}{$\begin{array}{l}(0) \\
\text { With } 0.4 \mathrm{~g} \\
\pm \text { SE } \\
\text { Sig. }\end{array}$}} & 39.4 & 35.9 & $28.8^{\mathrm{b}}$ & 46.7 & 95.1 \\
\hline & & 44.5 & 40.2 & $38.6^{\mathrm{a}}$ & 54.2 & 95.1 \\
\hline & & 2.86 & 2.23 & 0.05 & 1.64 & 1.23 \\
\hline & & NS & NS & 0.05 & NS & NS \\
\hline \multicolumn{7}{|c|}{ Interaction effect $(F R \times P R)$} \\
\hline \multirow{2}{*}{ Ad-lib } & 0 & $29 .^{7 \mathrm{c}}$ & $29.2^{b}$ & $26.3^{c}$ & $41.2^{\mathrm{c}}$ & $88.9^{b}$ \\
\hline & 0.4 & $43.1^{\mathrm{abc}}$ & $36.7^{\mathrm{ab}}$ & $39.8^{\mathrm{a}}$ & $54.7^{\mathrm{ab}}$ & $96.3^{\mathrm{a}}$ \\
\hline \multirow{2}{*}{$120 \%$} & 0 & $37.6^{\mathrm{bc}}$ & $40.9^{\mathrm{ab}}$ & $27.6^{\mathrm{c}}$ & $47.2^{\mathrm{bc}}$ & $96.3^{\mathrm{a}}$ \\
\hline & 0.4 & $55.6^{\mathrm{a}}$ & $36.4^{\mathrm{ab}}$ & $37.2^{\mathrm{a}}$ & $50.6^{\mathrm{ab}}$ & $100.0^{\mathrm{a}}$ \\
\hline \multirow{2}{*}{$140 \%$} & 0 & $51.0^{\mathrm{ab}}$ & $37.5^{\mathrm{ab}}$ & $32.4^{\mathrm{b}}$ & $51.6^{\mathrm{ab}}$ & $100.0^{\mathrm{a}}$ \\
\hline & 0.4 & $35.0^{\mathrm{bc}}$ & $47.7^{\mathrm{a}}$ & $38.8^{\mathrm{a}}$ & $57.2^{\mathrm{a}}$ & $88.9 b$ \\
\hline \multicolumn{2}{|c|}{$\pm \mathrm{SE}$} & 4.95 & 3.86 & 1.15 & 2.84 & 2.14 \\
\hline \multicolumn{2}{|c|}{ Sig. } & 0.05 & 0.05 & 0.05 & 0.05 & 0.05 \\
\hline
\end{tabular}

= Performance index; ${ }^{2}=$ viability; ${ }^{3}=$ total bacterial count $\left(\mathrm{x} 10^{7}\right)$ germ counts expressed in CFU/g caecal digesta; ${ }^{4}=$ Lactic acid bacteria $\left({\left.\mathrm{x} 10^{4}\right)}^{4}\right.$ germ counts expressed in CFU/g caecal digesta; a, b, c, d: means in the same column bearing different superscripts are significantly different $(\mathrm{P} \leq 0.05)$. NS= Non-significant

The most remarkable result is that the ad libitum diet with $\mathrm{PR}, \mathrm{FR}_{120}$ with PR and FR $\mathrm{F}_{140}$ with or without PR increased PI and the most interaction treatments improved V\%, these results may be due to FR sometimes decreases the incidence of post-weaning digestive disorders (Di Meo et al., 2007), and PR supplementation improves intestinal environment and gut health directly influence the health status and growth performance of animals due to better nutrient absorption in the gut (Pogány Simonová et al., 2015). 


\section{Nutrients digestibility, nitrogen $(N)$ and ash retention:}

The effect of FR system, PR product and their interaction on nutrients digestibility is presented in Table 5. According to these results the $\mathrm{FR}_{140}$ did not cause any detrimental effect on digestibility of nutrients, but the sever FR caused to decrease values all these traits as compared to ad libitum feeding.

On the other hand, no significant influence of adding $0.4 \mathrm{~g}$ probiotic $/ \mathrm{kg}$ diet on all digestibility coefficients with exception ether extract where rabbits fed diet with probiotic had significantly lower digestibility ether extract than those fed control diet.

Regarding the interaction between FR and PR, the results illustrated that rabbits received $\mathrm{FR}_{120}$ with or without probiotic recorded the lowest values of nutrients digestibility coefficient. However, rabbits fed early $0.4 \mathrm{~g} \mathrm{PR} / \mathrm{kg}$ diet from 3 to 12 weeks with $\mathrm{FR}_{140}$ did not significant differ from the ad-libitum feeding but, only OM digestibility significantly increased due to $140 \%$ FR without adding probiotic, but rabbits fed $140 \%$ FR with probiotic resulted in a significant decrease in digestibility of OM compared to ad-libitum feeding.

The data obtained on nitrogen $(\mathrm{N})$ and ash retention as affected by FR, PR and their interaction is showed in Table 6. Results obtained clearly observed that $\mathrm{N}$ intake and retention from ad-libitum rabbits were significantly $(\mathrm{P} \leq 0.05)$ higher than that recorded by restricted groups. Nitrogen excretion and ash retention did not significantly affected by restricted feeding up to $120 \%$ of energy for maintenance.

No significant influence of dietary probiotics on $\mathrm{N}$ and ash retention could be detected. However, results of $\mathrm{N}$ intake did not come strange where all treatments resulted in a significant decrease in $\mathrm{N}$ intake except for ad libitum feeding with adding probiotics and FR by $140 \%$ of energy for maintenance with probiotics when compared to the control group.

The interaction between FR and PR had no significant effect on $\mathrm{N}$ excretion and ash retention while, ad libitum rabbits had significantly higher $\mathrm{N}$ retention than those fed a restricted $\operatorname{diet}\left(\mathrm{FR}_{120}\right)$ with or without probiotics.

The results illustrated that dietary $\mathrm{FR}_{120}$ (severe FR) had the least values in digestibility of nutrients, this is consist with Gidenne et al., (2009) who mentioned that OM and NDF digestion significantly decreased by FR (80\% of control) from 35 to 68 day of age. This results may attributed to the reduction in digestive enzymes as a result of restriction strategy in the study by (Beshara et al., 2017) where the ileal villus height and area, as well as crypt depth, increased after weaning (Gallois et al., 2005) thus the severe FR during the grower period may be due to impairs the maturation of the gut that develops quickly in the young rabbit. However, the moderate FR resulted in non- 
Table (5): Effect of feed restriction system, probiotics product and their interaction between them on nutrients digestibility of grower rabbits at 12 weeks of age

\begin{tabular}{|c|c|c|c|c|c|c|c|c|}
\hline \multirow{2}{*}{\multicolumn{2}{|c|}{ Fraits }} & \multicolumn{7}{|c|}{ Digestibility of nutrients } \\
\hline & & $\overline{D M}$ & $\mathbf{C P}$ & $\mathbf{E E}$ & $\mathbf{C F}$ & OM & NFE & TDN \\
\hline \multicolumn{9}{|c|}{ Feed restriction system $(F R)$} \\
\hline \multicolumn{2}{|l|}{ Ad-lib } & $68.1^{\mathrm{a}}$ & $77.5^{\mathrm{a}}$ & $61.2^{\mathrm{a}}$ & $32.9^{\mathrm{ab}}$ & $72.5^{\mathrm{a}}$ & $82.1^{\mathrm{a}}$ & $55.8^{\mathrm{a}}$ \\
\hline \multicolumn{2}{|c|}{$120 \%$} & $48.1^{\mathrm{b}}$ & $63.5^{\mathrm{b}}$ & $48.3^{\mathrm{b}}$ & $24.1^{\mathrm{b}}$ & $56.1^{\mathrm{b}}$ & $71.6^{\mathrm{b}}$ & $46.9^{b}$ \\
\hline \multicolumn{2}{|c|}{$140 \%$} & $64.2^{\mathrm{a}}$ & $75.0^{\mathrm{a}}$ & $65.0^{\mathrm{a}}$ & $41.2^{\mathrm{a}}$ & $69.5^{\mathrm{a}}$ & $79.5^{\mathrm{a}}$ & $55.6^{\mathrm{a}}$ \\
\hline \multicolumn{2}{|l|}{$\pm \mathrm{SE}$} & 2.33 & 1.67 & 2.02 & 3.39 & 2.01 & 1.88 & 1.27 \\
\hline \multicolumn{2}{|c|}{ Sig. } & 0.05 & 0.05 & 0.05 & 0.05 & 0.05 & 0.05 & 0.05 \\
\hline \multicolumn{9}{|c|}{ Probiotics product $(P R)$} \\
\hline \multicolumn{2}{|c|}{ (0) } & 60.9 & 72.6 & $61.1^{\mathrm{a}}$ & 33.5 & 66.9 & 78.6 & 53.5 \\
\hline \multicolumn{2}{|l|}{$0.4 \mathrm{~g}$} & 59.3 & 71.4 & $55.3^{\mathrm{b}}$ & 31.9 & 65.2 & 76.8 & 52.0 \\
\hline \multicolumn{2}{|l|}{$\pm \mathrm{SE}$} & 1.90 & 1.36 & 1.65 & 2.77 & 1.63 & 1.53 & 1.04 \\
\hline \multicolumn{2}{|c|}{ Sig. } & NS & NS & 0.05 & NS & NS & NS & NS \\
\hline \multicolumn{9}{|c|}{ Interaction effect $(F R \times P R)$} \\
\hline \multirow{2}{*}{ Ad-lib } & 0 & $70.1^{\mathrm{a}}$ & $79.1^{\mathrm{a}}$ & $64.6^{\mathrm{ab}}$ & $34.1^{\mathrm{b}}$ & $74.3^{\mathrm{a}}$ & $84.1^{\mathrm{a}}$ & $57.2^{\mathrm{a}}$ \\
\hline & 0.4 & $66.1^{\mathrm{ab}}$ & $75.9^{\mathrm{a}}$ & $57.9^{\mathrm{b}}$ & $31.6^{\mathrm{b}}$ & $70.7^{\mathrm{ab}}$ & $80.1^{\mathrm{ab}}$ & $54.3^{\mathrm{ab}}$ \\
\hline \multirow{2}{*}{$\begin{array}{c}120 \\
\%\end{array}$} & 0 & $42.9^{\mathrm{d}}$ & $59.9^{\mathrm{c}}$ & $48.4^{\mathrm{c}}$ & $15.5^{\mathrm{c}}$ & $51.4^{\mathrm{d}}$ & $68.3^{\mathrm{c}}$ & $43.7^{\mathrm{c}}$ \\
\hline & 0.4 & $53.4^{\mathrm{c}}$ & $67.1^{\mathrm{bc}}$ & $48.3^{\mathrm{c}}$ & $32.7^{\mathrm{b}}$ & $60.9^{c}$ & $74.9^{\mathrm{bc}}$ & $50.2^{\mathrm{b}}$ \\
\hline \multirow{2}{*}{$140 \%$} & 0 & $69.8^{\mathrm{a}}$ & $78.7^{\mathrm{a}}$ & $70.3^{\mathrm{a}}$ & $50.9^{\mathrm{a}}$ & $74.9^{\mathrm{a}}$ & $83.5^{\mathrm{ab}}$ & $59.6^{\mathrm{a}}$ \\
\hline & 0.4 & $58.5^{\mathrm{bc}}$ & $71.3^{\mathrm{ab}}$ & $59.7^{\mathrm{b}}$ & $31.5^{\mathrm{b}}$ & $64.0^{\mathrm{bc}}$ & $75.5^{\mathrm{abc}}$ & $51.7^{\mathrm{ab}}$ \\
\hline \multicolumn{2}{|c|}{$\pm \mathrm{SE}$} & 3.29 & 2.36 & 2.85 & 4.80 & 2.84 & 2.66 & 1.79 \\
\hline \multicolumn{2}{|c|}{ Sig. } & 0.05 & 0.05 & 0.05 & 0.05 & 0.05 & 0.05 & 0.05 \\
\hline
\end{tabular}

a, b, c: Means in the same column bearing different superscripts are significantly different $(\mathrm{P} \leq 0.05) . \quad \mathrm{NS}=$ Non-significant

significantly improvement in digestibility of EE and CF by 6.2 and $12.5 \%$ respectively. In agreement with these results, Gidenne and Feugieir (2009) found that no significant influence due to dietary FR (80,70 and 60\% of ad libitum diet) from 35 day (age at weaning) to 54 day of age on $\mathrm{OM}, \mathrm{CP}$ and NDF digestion. Also, these results agree with Xiccato and Trocino (2010) who mentioned that a moderate FR in growing rabbits could be used with some advantages such as increase digestive efficiency modifies the partition of body energy retention as protein instead of fat. 
Table (6): Effect of feed restriction system, probiotics product and their interaction between them on nitrogen and ash retention of grower rabbits at 12 weeks of age

\begin{tabular}{|c|c|c|c|c|c|}
\hline \multirow{2}{*}{\multicolumn{2}{|c|}{ Factors }} & \multicolumn{4}{|c|}{ Nitrogen and ash retention } \\
\hline & & N intake (g/rabbit) & $\begin{array}{l}\text { N excreta } \\
\text { (g/rabbit) }\end{array}$ & $\begin{array}{c}\text { N retention } \\
(\%)\end{array}$ & $\begin{array}{c}\text { Ash retention } \\
(\%)\end{array}$ \\
\hline \multicolumn{6}{|c|}{ Feed restriction system $(F R)$} \\
\hline \multicolumn{2}{|l|}{ Ad-lib } & $3.87^{\mathrm{a}}$ & 0.87 & $77.50^{\mathrm{a}}$ & 39.03 \\
\hline \multicolumn{2}{|l|}{$120 \%$} & $2.54^{\mathrm{c}}$ & 0.92 & $63.50^{\mathrm{b}}$ & 39.74 \\
\hline \multicolumn{2}{|c|}{$140 \%$} & $3.18^{\mathrm{b}}$ & 0.80 & $74.98^{\mathrm{a}}$ & 41.30 \\
\hline \multicolumn{2}{|c|}{$\pm \mathrm{SE}$ mean } & 0.10 & 0.06 & 1.67 & 3.14 \\
\hline \multicolumn{2}{|c|}{ Sig. } & 0.05 & NS & 0.05 & NS \\
\hline \multicolumn{6}{|c|}{ Probiotics product $(P R)$} \\
\hline \multicolumn{2}{|l|}{ (0) } & 3.23 & 0.84 & 72.56 & 41.17 \\
\hline \multicolumn{2}{|l|}{$0.4 \mathrm{~g}$} & 3.16 & 0.89 & 71.43 & 38.87 \\
\hline \multicolumn{2}{|l|}{$\pm \mathrm{SE}$} & 0.08 & 0.05 & 1.36 & 2.56 \\
\hline \multicolumn{2}{|c|}{ Sig. } & NS & NS & NS & NS \\
\hline \multicolumn{6}{|c|}{ Interaction effect $(F R x P R)$} \\
\hline \multirow{4}{*}{$\begin{array}{c}\text { Ad-lib } \\
120 \\
\%\end{array}$} & 0 & $4.20^{\mathrm{a}}$ & 0.88 & $79.14^{\mathrm{a}}$ & 42.31 \\
\hline & 0.4 & $3.55^{\mathrm{ab}}$ & 0.86 & $75.87^{\mathrm{a}}$ & 35.75 \\
\hline & 0 & $2.40^{\mathrm{d}}$ & 0.96 & $59.89^{c}$ & 34.92 \\
\hline & 0.4 & $2.67^{\mathrm{cd}}$ & 0.87 & $67.11^{\mathrm{bc}}$ & 44.56 \\
\hline \multirow{2}{*}{$140 \%$} & 0 & $3.09^{\mathrm{bc}}$ & 0.67 & $78.65^{\mathrm{a}}$ & 46.29 \\
\hline & 0.4 & $3.27^{\mathrm{ab}}$ & 0.94 & $71.32^{\mathrm{ab}}$ & 36.31 \\
\hline \multirow{2}{*}{\multicolumn{2}{|c|}{$\begin{array}{c} \pm \text { SE mean } \\
\text { Sig. }\end{array}$}} & 0.14 & 0.09 & 2.36 & 4.44 \\
\hline & & 0.05 & NS & 0.05 & NS \\
\hline
\end{tabular}

$\mathrm{a}, \mathrm{b}, \mathrm{c}, \mathrm{d}$ : means in the same column bearing different superscripts are significantly different $(\mathrm{P} \leq 0.05)$. NS $=$ Non-significant

Regarding probiotic product, no significant alternations were occurred in nutrients digestibility due to inclusion PR in diet of growing rabbits except for EE digestibility, an observation that agrees with Oso et al. (2013) who found that the apparent nutrient digestibility values were not affect by dietary inclusion of probiotics in growing rabbits. While, Amber et al. (2014) showed that rabbits start fed diet with probiotic (Bio-Plus ${ }^{\circledR}$ 2B, Bacillus subtilis and Bacillus licheniformis) early from 3 to 13 weeks of age had significantly higher $\mathrm{CP}, \mathrm{CF}, \mathrm{NFE}$ and TDN digestion compared to control die. 


\section{Cecum microbial:}

The results in Table 7 illustrated that rabbits fed ad libitum with PR system and $\mathrm{FR}_{120}$ without PR tend to significantly lower TBC than control diet while the opposite was true in terms of rabbits fed $\mathrm{FR}_{120}$ with PR and those fed $\mathrm{FR}_{140}$ without $\mathrm{PR}$ as compared to control group. When the grower rabbits fed PR early with $\mathrm{FR}_{120}, \mathrm{LAB}$ was significantly higher than control and other dietary interactions. Also, rabbits fed FR120 with PR and FR140 with or without PR resulted in a significant decrease in LAB/TBC as compared to control diet.

As for PR product on cecum microbial, these results are contradict with the results of Abdel-Azeem et al. (2009), who found that addition of Bioplus 2B (400 mg/ kg diet) in rabbit diets reduced number of total bacterial count in caecum content of rabbits. However, the reduced caecal LAB/TBC obtained from rabbits fed PR in current study when compared to those fed control diet could be implicative of positive health status (Casey et al., 2007).

\section{Serum biochemical:}

As shown in Table 8, it is noticed that total protein and globulin significantly decreased due to $\mathrm{FR}_{140}$ but no significant influence on albumin as compared to ad libitum diet (Table 7). It is evident that ad libitum feeding significantly $(\mathrm{P} \leq 0.05)$ decreased serum triglyceride but no significant effect in serum cholesterol due to $\mathrm{FR}_{120}$ and $\mathrm{FR}_{140}$ as compared to ad libitum diet.

As a rule, the results indicated that the diet supplemented with probiotics product early from 3 weeks of age resulted in no significant differences in total protein, albumin and triglycerides while, cholesterol significantly decreased compared to the control diet.

In addition, the present study showed that grower rabbits fed $\mathrm{FR}_{120}$ with PR product and $\mathrm{FR}_{140}$ with or without PR recorded significantly lower total protein than control rabbits. But, statistical analysis could not reveal any significant differences among ad libitum diet and treatments in respect of serum albumin. On the other hand, both rabbits received $\mathrm{FR}_{120}$ with $\mathrm{PR}$ and those fed $\mathrm{FR}_{140}$ without PR recorded the lowest value of globulin as compared to control diet. All dietary interactions treatments resulted in a significant increase triglycerides while, the lowest value of serum cholesterol was observed by feeding on $\mathrm{FR}_{120}$ and $\mathrm{FR}_{140}$ without or with $\mathrm{PR}$ as compared to the control diet.

In respect of the effect of probiotic product, the results seems to contradict with findings by (Amber et al., 2014) who reported that serum total 
Table (7): Effect of feed restriction system, probiotics product and their interaction between them on performance index, viability and microbial activity of grower rabbits

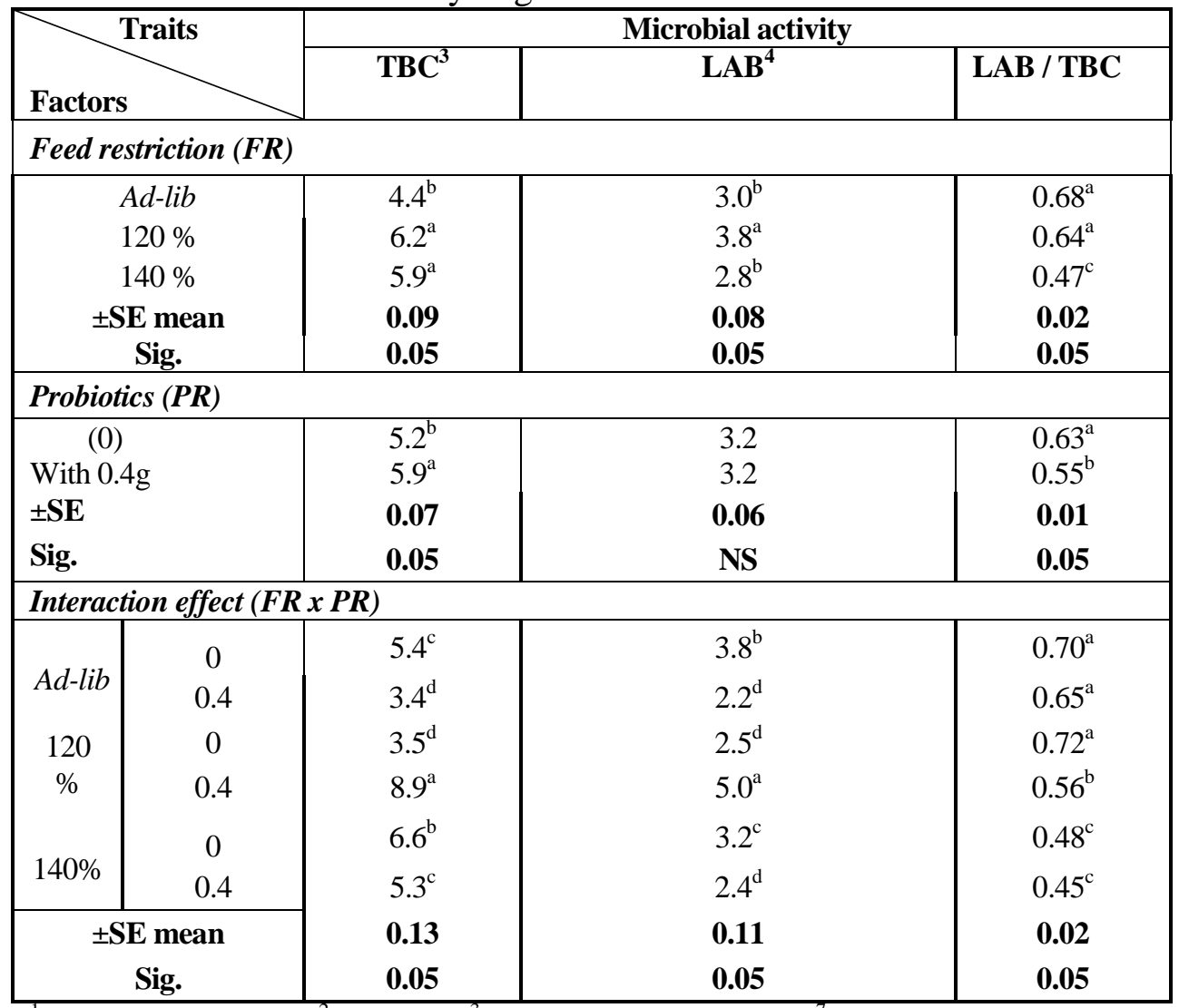

= Performance index; ${ }^{2}=$ viability $;^{3}=$ total bacterial count $\left(\times 10^{7}\right)$ germ counts expressed in

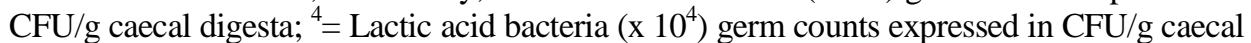
digesta; $a, b, c, d$ : means in the same column bearing different superscripts are significantly different $(\mathrm{P} \leq 0.05) . \quad \mathrm{NS}=$ Non-significant

protein, albumin and globulin significantly increased with supplementing BioMos, Bio-Plus or their mix in diets. On the other hand, as for serum cholesterol, the results are in agreement with those reported by (El-deek et al., 2013; Amber et al., 2014). Lye et al., (2010) who showed that there existed five possible probiotic mechanisms including assimilation of cholesterol during growth, binding of cholesterol to cellular surface, disruption of cholesterol micelle, deconjugation of bile salt and bile salt hydrolase activity. 
Table (8): Effect of feed restriction system, probiotics product and their interaction between them on some serum biochemical of grower rabbits at 12 weeks of age

\begin{tabular}{|c|c|c|c|c|c|c|c|}
\hline \multirow{2}{*}{\multicolumn{2}{|c|}{ Fraits }} & \multicolumn{6}{|c|}{ Serum biochemical } \\
\hline & & $\begin{array}{l}\text { Total } \\
\text { protein } \\
(\mathrm{g} / \mathrm{dl}) *\end{array}$ & $\begin{array}{c}\text { Albumin } \\
\text { (A) } \\
(\mathrm{g} / \mathrm{dl})^{*}\end{array}$ & $\begin{array}{l}\text { Globulin } \\
\text { (G) (g/dl) }\end{array}$ & $\mathrm{A} / \mathrm{G}$ ratio & $\begin{array}{c}{ }^{1} \text { Trig } \\
\text { (mg/dl) }\end{array}$ & $\begin{array}{c}{ }^{2} \text { Chol } \\
\text { (mg/dl) }\end{array}$ \\
\hline \multicolumn{8}{|c|}{ Feed restriction $(F R)$} \\
\hline \multicolumn{2}{|c|}{ Ad-lib } & $5.4^{\mathrm{a}}$ & 3.11 & $2.29^{\mathrm{a}}$ & 1.37 & $108.0^{\mathrm{b}}$ & 78.5 \\
\hline \multicolumn{2}{|l|}{$120 \%$} & $5.3^{\mathrm{a}}$ & 3.09 & $2.18^{\mathrm{a}}$ & 1.42 & $126.0^{\mathrm{a}}$ & 75.0 \\
\hline \multicolumn{2}{|l|}{$140 \%$} & $4.9^{\mathrm{b}}$ & 2.96 & $1.93^{\mathrm{b}}$ & 1.56 & $122.5^{\mathrm{a}}$ & 72.0 \\
\hline \multicolumn{2}{|c|}{ \pm SE mean } & 0.07 & 0.05 & 0.07 & 0.06 & 2.76 & 2.14 \\
\hline \multicolumn{2}{|l|}{ Sig. } & 0.05 & NS & 0.05 & NS & 0.05 & NS \\
\hline \multicolumn{8}{|c|}{ Probiotics (PR) } \\
\hline \multicolumn{2}{|c|}{ (0) } & $5.3^{\mathrm{a}}$ & $3.12^{\mathrm{a}}$ & 2.18 & 1.46 & $103.3^{\mathrm{b}}$ & $94.7^{\mathrm{a}}$ \\
\hline \multicolumn{2}{|c|}{ With $0.4 \mathrm{~g}$} & $5.1^{\mathrm{b}}$ & $2.98^{\mathrm{b}}$ & 2.09 & 1.44 & $114.7^{\mathrm{a}}$ & $75.3^{\mathrm{b}}$ \\
\hline \multicolumn{2}{|c|}{$\pm \mathrm{SE}$} & 0.05 & 0.04 & 0.06 & 0.09 & 2.25 & 1.75 \\
\hline \multicolumn{2}{|l|}{ Sig. } & 0.05 & 0.05 & NS & NS & 0.05 & 0.05 \\
\hline \multicolumn{8}{|c|}{ Interaction effect (FR $x$ PR) } \\
\hline \multirow{4}{*}{$\begin{array}{c}\text { Ad- } \\
\text { lib } \\
120 \\
\%\end{array}$} & 0 & $5.4^{\mathrm{a}}$ & $3.04^{\mathrm{ab}}$ & $2.40^{\mathrm{a}}$ & $1.27^{\mathrm{b}}$ & $72^{\mathrm{e}}$ & $143^{\mathrm{a}}$ \\
\hline & 0.4 & $5.4^{\mathrm{a}}$ & $3.18^{\mathrm{a}}$ & $2.19^{\mathrm{ab}}$ & $1.47^{\mathrm{ab}}$ & $85^{\mathrm{d}}$ & $73^{\mathrm{ab}}$ \\
\hline & 0 & $5.6^{\mathrm{a}}$ & $3.27^{\mathrm{a}}$ & $2.35^{\mathrm{a}}$ & $1.40^{\mathrm{b}}$ & $130^{\mathrm{ab}}$ & $77^{\mathrm{b}}$ \\
\hline & 0.4 & $4.9^{\mathrm{b}}$ & $2.90^{\mathrm{b}}$ & $2.00^{\mathrm{c}}$ & $1.45^{\mathrm{ab}}$ & $222^{\mathrm{b}}$ & $73^{\mathrm{ab}}$ \\
\hline \multirow{2}{*}{$140 \%$} & 0 & $4.8^{\mathrm{b}}$ & $3.04^{\mathrm{ab}}$ & $1.78^{\mathrm{bc}}$ & $1.71^{\mathrm{a}}$ & $108^{\mathrm{c}}$ & $64^{c}$ \\
\hline & 0.4 & $4.9^{\mathrm{b}}$ & $2.87^{b}$ & $2.07^{\mathrm{abc}}$ & $1.41^{\mathrm{b}}$ & $137^{\mathrm{a}}$ & $80^{\mathrm{b}}$ \\
\hline \multicolumn{2}{|c|}{$\pm \mathrm{SE}$} & 0.09 & 0.07 & 0.10 & 0.09 & 3.90 & 3.04 \\
\hline \multicolumn{2}{|c|}{ Sig. } & 0.05 & 0.05 & 0.05 & 0.05 & 0.05 & 0.05 \\
\hline
\end{tabular}

${ }^{1}$ trig, triglycerides; ${ }^{2 \text { chol }}$, cholesterol; $*$ The normal range of total protein and albumin is 4.5 to $12.2 \mathrm{~g} / \mathrm{dl}$ and 2.7 to $4.3 \mathrm{~g} / \mathrm{dl}$ respectively (Ozkan et al., 2012);

$\mathrm{a}, \mathrm{b}, \mathrm{c}$..: Means in the same column bearing different superscripts are significantly different $(\mathrm{P} \leq 0.05) . \quad \mathrm{NS}=$ Non-significant;

\section{Hematology traits:}

The results in Table 9 illustrated that grower rabbits fed $\mathrm{FR}_{120}$ resulted in a significant decrease in the most of hematology traits while, a significant improvement in lymphocyte cells (L) was achieved by the $\mathrm{FR}_{140}$ as compared to ad libitum diet.

Concerning PR treatment, grower rabbits fed PR early at 3 weeks of age recorded significantly the highest values of red blood cells (RBC), hematocrits 
Table (9): Effect of feed restriction system, probiotics product and their interaction between them on hematology traits of grower rabbits at 12 weeks of age

\begin{tabular}{|c|c|c|c|c|c|c|c|c|c|c|}
\hline \multirow{2}{*}{\multicolumn{2}{|c|}{ Factors }} & \multicolumn{9}{|c|}{ Hematology traits } \\
\hline & & $\begin{array}{c}{ }^{1} \mathrm{RBC} \\
\left(\mathbf{x 1 0 ^ { 1 2 }}\right)\end{array}$ & $\begin{array}{c}{ }^{2} \mathrm{HCT} \\
\%\end{array}$ & $\begin{array}{l}{ }^{3} \mathrm{HEB} \\
\text { (g/dl) }\end{array}$ & $\begin{array}{l}{ }^{4} \mathbf{W B C} \\
(\mathbf{x 1 0})\end{array}$ & ${ }^{5} \mathrm{~L} \%$ & ${ }^{6} \mathbf{N} \%$ & $\mathrm{~N} / \mathrm{L}$ & $\begin{array}{l}{ }^{7} \mathbf{M} \\
\%\end{array}$ & ${ }^{8} \mathrm{E} \%$ \\
\hline \multicolumn{11}{|c|}{ Feed restriction (FR) } \\
\hline \multicolumn{2}{|c|}{ Ad-lib } & $5.44^{\mathrm{a}}$ & $33.1^{\mathrm{a}}$ & $11.1^{\mathrm{a}}$ & $7.1^{\mathrm{a}}$ & $25.5^{\mathrm{b}}$ & $68.0^{\mathrm{ab}}$ & $2.7^{\mathrm{a}}$ & 4.0 & 2.5 \\
\hline \multicolumn{2}{|l|}{$120 \%$} & $4.10^{\mathrm{b}}$ & $27.5^{\mathrm{b}}$ & $9.3^{\mathrm{b}}$ & $6.1^{\mathrm{b}}$ & $28.5^{\mathrm{a}}$ & $66.5^{\mathrm{b}}$ & $2.3^{\mathrm{b}}$ & 3.0 & 1.8 \\
\hline \multicolumn{2}{|l|}{$140 \%$} & $5.41^{\mathrm{a}}$ & $32.5^{\mathrm{a}}$ & $11.1^{\mathrm{a}}$ & $6.2^{\mathrm{b}}$ & $24.0^{\mathrm{b}}$ & $70.0 \mathrm{a}$ & $2.9^{\mathrm{a}}$ & 3.83 & 2.2 \\
\hline \multicolumn{2}{|l|}{$\pm \mathrm{SE}$} & 0.13 & 0.31 & 0.13 & 0.11 & 0.90 & 1.0 & 0.11 & 0.58 & 0.70 \\
\hline \multicolumn{2}{|l|}{ Sig. } & 0.05 & 0.05 & 0.05 & 0.05 & 0.05 & 0.05 & 0.05 & NS & NS \\
\hline \multicolumn{11}{|c|}{ Probiotics $(P R)$} \\
\hline \multicolumn{2}{|c|}{ (0) } & $4.53^{\mathrm{b}}$ & $29.0^{\mathrm{b}}$ & $9.7^{b}$ & $6.9^{\mathrm{a}}$ & 26.0 & $67.7^{\mathrm{b}}$ & 2.6 & $3.8^{\mathrm{a}}$ & 2.4 \\
\hline \multicolumn{2}{|c|}{ With $0.4 \mathrm{~g}$} & $5.43^{\mathrm{a}}$ & $33.1^{\mathrm{a}}$ & $11.3^{\mathrm{a}}$ & $6.0^{\mathrm{b}}$ & 26.0 & $86.7^{\mathrm{a}}$ & 2.7 & $3.4^{\mathrm{b}}$ & 1.9 \\
\hline \multicolumn{2}{|c|}{$\pm \mathrm{SE}$} & 0.10 & 0.26 & 0.11 & 0.09 & 0.73 & 0.82 & 0.09 & 0.47 & 0.57 \\
\hline \multicolumn{2}{|l|}{ Sig. } & 0.05 & 0.05 & 0.05 & 0.05 & NS & 0.05 & NS & 0.05 & NS \\
\hline \multicolumn{11}{|c|}{ Interaction effect (FR $x P R)$} \\
\hline \multirow{2}{*}{ Ad-lib } & 0 & $5.29^{\mathrm{a}}$ & $32.0^{\mathrm{b}}$ & $10.5^{\mathrm{c}}$ & $7.6^{\mathrm{a}}$ & $25^{\mathrm{bc}}$ & $67^{\mathrm{b}}$ & $2.7^{\mathrm{b}}$ & 5.0 & 3.0 \\
\hline & 0.4 & $5.58^{\mathrm{a}}$ & $34.2^{\mathrm{a}}$ & $11.6^{\mathrm{a}}$ & $6.6^{\mathrm{bc}}$ & $26^{\mathrm{abc}}$ & $69^{\mathrm{ab}}$ & $2.7^{\mathrm{b}}$ & 3.0 & 2.0 \\
\hline \multirow{2}{*}{$\begin{array}{c}120 \\
\%\end{array}$} & 0 & $2.10^{\mathrm{b}}$ & $22.6^{\mathrm{c}}$ & $7.6^{\mathrm{d}}$ & $7.0^{\mathrm{b}}$ & $27 \mathrm{ab}$ & $68^{\mathrm{ab}}$ & $2.5^{\mathrm{bc}}$ & 2.7 & 2.0 \\
\hline & 0.4 & $5.20^{\mathrm{a}}$ & $32.3^{\mathrm{b}}$ & $11.0^{\mathrm{bc}}$ & $5.2^{\mathrm{d}}$ & $30^{\mathrm{abc}}$ & $65^{\mathrm{b}}$ & $2.2^{\mathrm{c}}$ & 3.3 & 1.7 \\
\hline \multirow[b]{2}{*}{$140 \%$} & 0 & $5.30^{\mathrm{a}}$ & $32.3^{\mathrm{b}}$ & $10.9^{\mathrm{bc}}$ & $6.2^{\mathrm{c}}$ & $26^{\mathrm{a}}$ & $68^{\mathrm{ab}}$ & $2.6^{\mathrm{bc}}$ & 3.7 & 2.3 \\
\hline & 0.4 & $5.51^{\mathrm{a}}$ & $32.7^{\mathrm{b}}$ & $11.2^{\mathrm{ab}}$ & $6.2^{\mathrm{c}}$ & $22^{\mathrm{c}}$ & $72^{\mathrm{a}}$ & $3.3^{\mathrm{a}}$ & 4.0 & 2.0 \\
\hline \multicolumn{2}{|c|}{$\pm \mathrm{SE}$} & 0.18 & 0.44 & 0.18 & 0.15 & 1.27 & 1.41 & 0.09 & 0.82 & 0.99 \\
\hline \multicolumn{2}{|c|}{ Sig. } & 0.05 & 0.05 & 0.05 & 0.05 & 0.05 & 0.05 & 0.05 & NS & NS \\
\hline
\end{tabular}

RBC, Red blood cells; ${ }^{2} \mathrm{HCT}$, Hematocrit; ${ }^{3} \mathrm{HEB}$, Hemoglobin; ${ }^{4} \mathrm{WBC}$, White bold cells, ${ }^{5} \mathrm{~L}$, Lymphocytes; ${ }^{6} \mathrm{~N}$, Neutrophils; ${ }^{7} \mathrm{M}$, Monocytes; ${ }^{8} \mathrm{E}$, Eosinophil; The normal range of $\mathrm{RBC}=$ $5.5 \pm 0.3\left(10^{\wedge} 12 / \mathrm{L}\right), \mathrm{HCT}=31.1 \pm 2.2 \%, \mathrm{HEB}=11.5 \pm 0.8(\mathrm{~g} / \mathrm{dl}), \mathrm{WBC}=7 \pm 2.1\left(10^{\wedge} 9 / \mathrm{L}\right), \mathrm{L}=$ $29 \pm 15 \%, \mathrm{~N}=51 \pm 0.3 \%$ ( Archetti et al., 2008); a, b, c, d: means in the same column bearing different superscripts are significantly different $(\mathrm{p} \leq 0.05)$. NS = non-significant;

(HCT), hemoglobin (HEB) and L\% compared to control diet. On the other hand, both white blood cells (WBC) and monocytes (M) \% significantly decrease by dietary PR. No significant effect of PR diet on N\%, N/L and eosinophil cells could be detected.

In terms of interaction between FR and PR, the results showed that grower rabbits fed $\mathrm{FR}_{120}$ without PR had significantly the lowest value RBC, HCT, 
HEB and WBC. Also, the rabbits fed diet $\mathrm{FR}_{140}$ without PR supplementation tend to significantly lower WBC than those received ad libitum feeding while, the same treatment resulted in a significant increase in N\% and L\% compared to the control diet. Moreover, the ratio N/L increase significantly due to feeding on $\mathrm{FR}_{140}$ with PR early from 3 weeks of age when compared to ad libitum feeding while, regarding the feeding on $\mathrm{FR}_{120}$ with $\mathrm{PR} N / \mathrm{L}$ significantly decreased as compared to the control group. On the other hand, all dietary interaction treatments resulted in no significant effect on $\mathrm{M}$ and $\mathrm{E} \%$ compared to the ad libitum feeding.

Many metabolic parameters are modified under restriction, as reported for the rabbit by Van Harten and Cardoso (2010). The immune status of FR rabbits was briefly described through some blood characteristics, such as the cell profile. Tumova et al. (2007) reported an increased number of lymphocytes in FR rabbits. However, there is a dearth of information on the immune status of the growing rabbit.

The mode of action of probiotics is that enhance mucosal immunity of the host by eliciting production of immunoglobulin $\mathrm{A}$ as well as various cytokines including TNF- $\alpha$, IL-6, IL-10, and INT- $\gamma$ (Isolauri et al., 2001). Also, they produce specific and intermediate metabolites which stimulate the body immune systems (Sherman et al., 2009).

\section{Carcass quality}

In respect of carcass quality traits as shown in Table (10), no significant influence of all dietary treatments on carcass quality of grower rabbits at 12 weeks of age could be demonstrated with exception kidney, GIT and dressing\% where, restricted diet by $120 \%$ of energy for maintenance without probiotics resulted in a heavier kidney \% than ad libitum and other interaction treatments. Also, the dressing \% significantly increased due to ad libitum diet supplemented with0.4g probiotic/ $\mathrm{kg}$ diet while the same treatment resulted in a significant decrease in GIT as compared to the control diet.

The results illustrated that the dressing \% significantly increased while the opposite was true in respect of GIT\% when rabbits fed ad libitum diet with adding the probiotic product as compared to the control diet also, the same treatment had significantly higher weight gain than control group (Table 2), thus this increment in dressing\% may be due to the development in digestive tract depends on the weight gain (Je'rome et al., 1998). There are insignificant decreased in abdominal fat by FR, the reduction in abdominal fat due to FR may be a moderate FR in growing rabbits could be used with some advantages 
Table (10): Effect of feed restriction system, probiotics product and their interaction between them on carcass quality traits of grower rabbits at 12 weeks of age

\begin{tabular}{|c|c|c|c|c|c|c|c|c|c|c|}
\hline \multirow{3}{*}{\multicolumn{2}{|c|}{$\mathbf{T}_{\mathbf{1}}$}} & \multicolumn{9}{|c|}{ Carcass quality traits \% } \\
\hline & & \multirow{2}{*}{$\begin{array}{l}\text { BW } \\
\text { at sl. }{ }^{1}\end{array}$} & \multirow[b]{2}{*}{$\begin{array}{c}\text { Carcass } \\
\%\end{array}$} & \multicolumn{3}{|c|}{ Giblets \% } & \multirow{2}{*}{$\begin{array}{c}\mathbf{D R}^{2} \\
\%\end{array}$} & \multirow{2}{*}{$\begin{array}{c}\text { GIT }^{3} \\
\end{array}$} & \multirow{2}{*}{$\begin{array}{l}C^{4} \\
\%\end{array}$} & \multirow{2}{*}{$\begin{array}{c}\text { Ab. } \\
\text { Fat }^{5} \\
\%\end{array}$} \\
\hline & & & & Heart & Liver & Kidney & & & & \\
\hline \multicolumn{11}{|c|}{ Feed restriction system $(F R)$} \\
\hline \multicolumn{2}{|c|}{ Ad-lib } & 1635 & 56.3 & 0.33 & 3.91 & 0.78 & 61.4 & 18.9 & 7.06 & 0.99 \\
\hline \multicolumn{2}{|c|}{$120 \%$} & 1560 & 60.5 & 0.32 & 4.22 & 1.15 & 61.4 & 23.4 & 8.01 & 0.84 \\
\hline \multicolumn{2}{|c|}{$140 \%$} & 1599 & 56.0 & 0.31 & 4.59 & 0.82 & 61.9 & 21.7 & 7.08 & 0.61 \\
\hline \multicolumn{2}{|c|}{$\pm \mathrm{SE}$} & - & 2.85 & 0.26 & 0.26 & 0.13 & 0.79 & 1.64 & 0.82 & 0.17 \\
\hline \multicolumn{2}{|c|}{ Sig. } & - & NS & NS & NS & NS & NS & NS & NS & NS \\
\hline \multicolumn{11}{|c|}{ Probiotics product $(P R)$} \\
\hline \multirow{2}{*}{\multicolumn{2}{|c|}{$\begin{array}{l}(0) \\
0.4 \mathrm{~g}\end{array}$}} & 1604 & 58.1 & 0.33 & 4.22 & 1.03 & 60.5 & 23.0 & 8.34 & 0.75 \\
\hline & & 1789 & 57.1 & 0.31 & 4.27 & 0.80 & 62.5 & 19.6 & 6.43 & 0.88 \\
\hline \multicolumn{2}{|l|}{$\pm \mathrm{SE}$} & - & 2.32 & 0.03 & 0.21 & 0.11 & 0.65 & 1.34 & 0.67 & 0.14 \\
\hline \multicolumn{2}{|l|}{ Sig. } & - & NS & NS & NS & NS & NS & NS & NS & NS \\
\hline \multicolumn{11}{|c|}{ Interaction effect $(F R \times P R)$} \\
\hline \multirow{2}{*}{ Ad-lib } & 0 & 1382 & 54.0 & 0.32 & 3.80 & $0.74^{\mathrm{b}}$ & $58.9^{\mathrm{b}}$ & $21.2^{\mathrm{ab}}$ & 8.84 & 0.88 \\
\hline & 0.4 & 1890 & 58.7 & $0 . .35$ & 4.00 & $0.81^{\mathrm{b}}$ & $63.9^{\mathrm{a}}$ & $16.6^{\mathrm{b}}$ & 5.29 & 1.10 \\
\hline & 0 & 1320 & 64.3 & 0.36 & 4.26 & $1.54^{\mathrm{a}}$ & $60.9^{\mathrm{ab}}$ & $26.7^{\mathrm{a}}$ & 9.21 & 0.72 \\
\hline & 0.4 & 1798 & 56.7 & 0.28 & 4.18 & $0.76^{\mathrm{b}}$ & $61.8^{\mathrm{ab}}$ & $20.0^{\mathrm{ab}}$ & 6.81 & 0.96 \\
\hline \multirow[b]{2}{*}{$140 \%$} & 0 & 1518 & 56.0 & 0.32 & 4.60 & $0.80^{\mathrm{b}}$ & $61.7^{\mathrm{ab}}$ & $21.1^{\mathrm{ab}}$ & 6.97 & 0.64 \\
\hline & 0.4 & 1680 & 56.0 & 0.30 & 4.59 & $0.84^{\mathrm{b}}$ & $61.8^{\mathrm{ab}}$ & $22.3 a^{b}$ & 7.18 & 0.58 \\
\hline \multicolumn{2}{|c|}{$\pm \mathrm{SE}$} & - & 4.03 & 0.05 & 0.37 & 0.19 & 1.12 & 2.32 & 1.16 & 0.24 \\
\hline \multicolumn{2}{|c|}{ Sig. } & - & NS & NS & NS & 0.05 & 0.05 & 0.05 & NS & NS \\
\hline
\end{tabular}

$=$ Body weight at slaughter ${ }^{2}=$ dressing $\%,{ }^{3}=$ Gastrointestinal tract, ${ }^{4}=$ Cecum $^{5}=$ Abdominal fat $\mathrm{a}, \mathrm{b}, \mathrm{c}$ : means in the same column bearing different superscripts are significantly different ( $\mathrm{p}$ $\leq 0.05), \mathrm{NS}=$ Non-significant

such as increase digestive efficiency, modifies the partition of body energy retention as protein instead of fat (Xiccato and Trocino, 2010).

The results showed that no significant influence of dietary PR on carcass traits, these findings are contrary to the report of Amber et al., (2014) who showed that carcass percentage was significantly increased by supplementing Bio-Plus in growing rabbit's diet, also who reported that rabbits start fed experimental diets early (from 3 to 13 weeks of age) had significantly higher carcass percentage compared to those start fed experimental diets later (from 5 to 13 weeks of age). However, in agreement with theses results the same 
author showed that GIT decreased by BR in the diet also, there were no significant effects in carcass criteria due to PR in the diet of growing rabbits (El-Sagheer and Hassanein 2014).

\section{Economic efficiency:}

Results concerning the economic efficiency (EEF) are shown in Table 11. As EEF of fattening rabbits related to weight gain and the cost of feeding thus at sight on the results of the current study, it is shown that the greatest value of EEF was that produced by grower rabbits fed FR either FR $\mathrm{FR}_{120}$ or $\mathrm{FR}_{140}$ than ad libitum feeding as compared to the control group. But, no significant influence of dietary PR diet on EEF could be detected. In addition, it should be noted that all interaction treatments except for ad libitum with probiotic resulted in a significant higher EEF than caused by feeding on control diet.

As for FR, these results in agreement with Duperray and Gyonvarch, (2009) who reported that when an intake limitation strategy is applied, the margin on the feed cost is generally improved by $2 \%$ to $10 \%$. Also, Amber et $a l$. , (2014) reported that some economical traits as affected by dietary probiotic are shown.

Conclusively, the current study illustrated that rabbit's start fed PR product early from 3 till 12 weeks of age with $\mathrm{FR}_{120}$ post- weaning or rabbits fed $\mathrm{FR}_{140}$ with or without PR product showed be taken with considerable in the commercial exploitation of rabbits production for its high economically value, under the Egyptian environmental condition.

\section{REFERENCES}

Abdel-Azeem, F.; Hashim, N. A.; Badawi, Y. K. E. H.; and Farid, A., 2009. Comparative study between probiotic (Bioplus 2B) and antibiotic (lincofeed) on the performance of growing rabbits. Egypt. J. Rabbit Sci., 19(1): 7-22.

Amber, K. H.; Yakout, H. M.; and Hamed, R. S., 2004. Effect of feeding diets containing yucca extract or probiotic on growth, digestibility, nitrogen balance and caecal microbial activity of growing New Zealand white rabbits. In: Proceedings of the $8^{\text {th }}$ World Rabbit Congress, Puebla, Mexico, 7-10 September, pp:737-745.

Amber, K.h.; Fatma, M.; Abd El-Nabi, W. A Morsy and Shama H. A. Morsy (2014). Effect of dietary supplementation of probiotic and Prebiotic on preventing post weaning digestive Disorders and productive performance of growing Rabbits. Egypt. Poult. Sci., (34) (I): (19-38). 
Table (11): Effect of feed restriction system, probiotics product and their interaction between them on economic efficiency of grower rabbits at 14 weeks of age

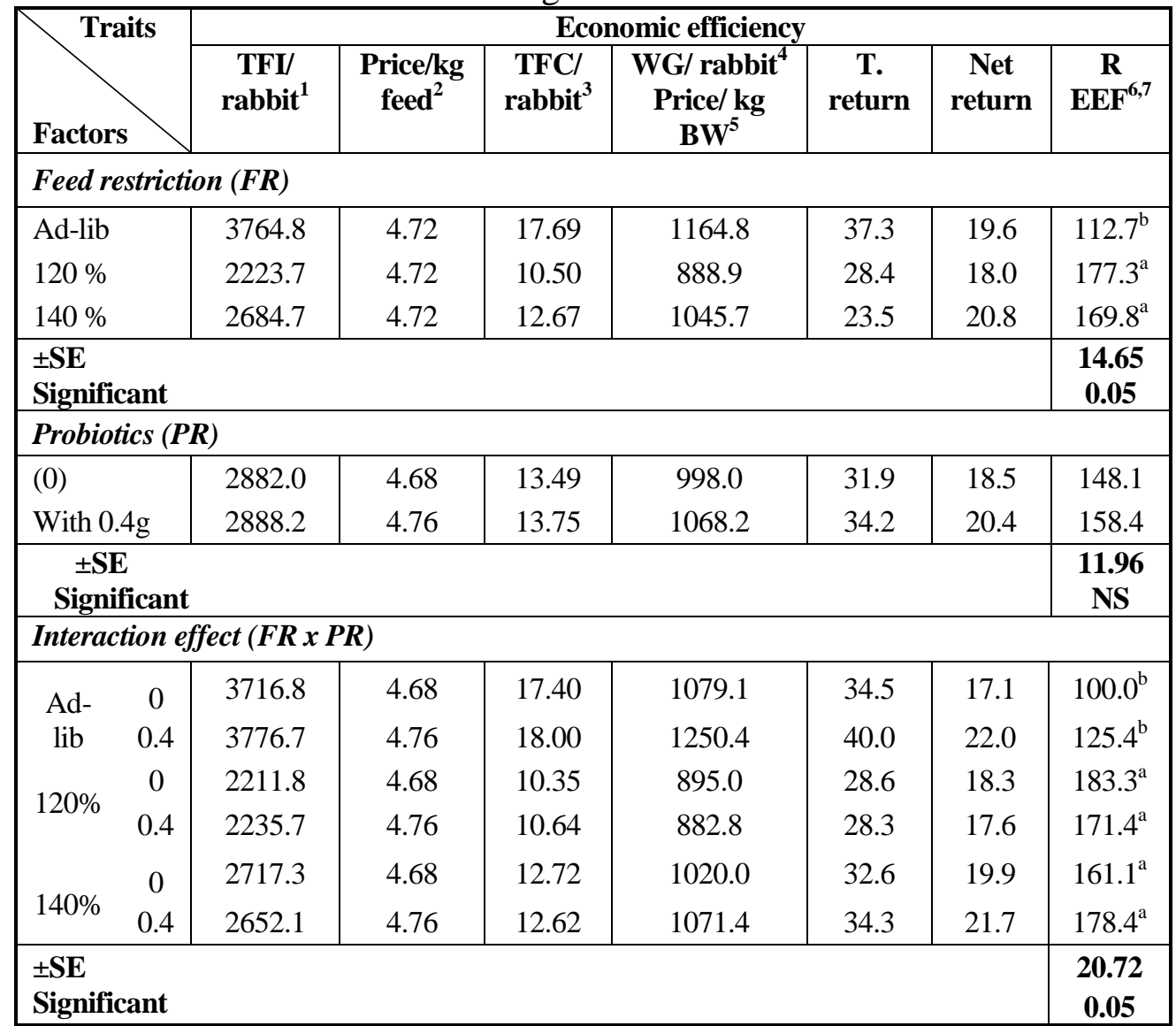

= Total feed intake/rabbit/overall period; ${ }^{2}$ Price $/ \mathrm{kg}$ feed= the price of $1 \mathrm{Kg}$ feed by Egyptian pound; $3=$ Total feed cost/rabbit; ${ }^{4}=$ Total weight gain/rabbit; ${ }^{5}=$ the price $1 \mathrm{Kg}$ of live body weight by Egyptian pound; ${ }^{6} \mathrm{EEF}=$ Economic efficiency $(\%)=($ Net return/Total feed cost $) \mathrm{x}$ $100 ;{ }^{7} \mathrm{R}$ FEE $=(\mathrm{EEF}$ of treatments/EEF of control diet) $\mathrm{x} 100 ; \mathrm{a} . \mathrm{b} . \mathrm{c}$ means in the same column bearing superscripts are significantly different $(\mathrm{P} \leq 0.05)$.

A.O.A.C., 2005. Association of Official Analytical Chemists. Official methods of analysis. 18th Ed. Published by the AOAC, Washington, D. C., USA.

Archetti, I.; Tittarelli, C.; Cerioli, M.; Brivio, R.; Grilli, G. and Lavazza A. (2008). Serum chemistry and hematology values in commercial rabits: preliminary data from industrial farms in northern Italy. 9th World Rabbit Congress-June 10-13, Verona-Italy. 
Beshara, M.M.; Ragab, M.A.; El Desoky, A.El.M.I.; Fahim, H.N.; ElFhhat, A.M.; Alazab. A.M. and El-gamal, A.A. (2017). Effect of feed restriction with supplementation of probiotic on productive and economical performance in local growing rabbits. Egypt. Poult. Sci. Vol (37) (II): (407-431).

Boisot P, Licois D and Gidenne T (2003). Feed restriction reduces the sanitary impact of an experimental reproduction of Epizootic Rabbit Enteropathy syndrome (ERE), in the growing rabbit. In 10e'me Journe' es de Recherches Cunicoles Franc, aises (ed. G Bolet), pp. 267-270. ITAVI publishing, Paris, France.

Casey, P.G.; Gardiner, G.E.; Casey,G.; Bradshaw, B.; Lawlor, P.G.; Lynch, P.B.; Leonard, F.C.; Stanton, C.; Ross, R.R.; Fitzgerald,G.F. and Colin,H. (2007). A five-strain probiotic combination reduces pathogen shedding and alleviates disease signs in pigs challenged with Salmonella enteric Serovarty phimurium. Appl.Environ.Microbiol.73, $1858-1863$.

Chichlowski, M.; Croom, J.; McBride, B.W.; Havenstein, G.B. and Koci, M.D. (2007). Metabolic and Physiological Impact of Probiotics or DirectFed-Microbials on Poultry: A Brief Review of Current Knowledge. International Journal of Poultry Science 6 (10): 694-704.

De Blas, J. C.; and Wiseman, J., 2010. 'Nutrition of the Rabbit' CABI Publishing (2nd Revised edition) Wallingford, Oxford.

Duncan, D.B., 1955. Multiple ranges and multiple f- test, Biometries 11: 1-42.

Di Meo, C.; Bovera, F.; Marono, S.; Vella, N.; and Nizza, A., 2007. Effect of feed restriction on performance and feed digestibility in rabbits. Italian Journal of Animal Science, 6, 765-767.

Duperray. J. and Gyonvarch, A. (2009). Effect of different quantitative feed restriction strategies on fattening performance, and interest of a high energy and protein feed. In Proceedings of the 13e'mes Journe' es de la Recherche Cunicole Franc, aise(ed. G Bolet), pp. 59-62. ITAVI Publishing, Le Mans, France.

El-deek, A.A.; Albanoby, M.A. and Manal K. Abou El- Naga (2013). Evaluation of super action probiotic as a natural growth promoter for growing rabbits . Egypt. Poult. Sci. (33) (ii): (407-419).

El-Sagheer, M. and Hassanein,H.H.M. (2014). Effect of enzymes and probiotic mixture supplementation to the diet of growing female rabbits on performance and carcass criteria. Egypt. Poult. Sci. Vol (34) (I): (259272) 
FEDNA, 2013. Nutritional guidelines for feeding pet rabbits. European pet food industry federation/ Av. Louse 89/ B- Bruxells/ www.fediar.org.

Gallois, M.; Gidenne, T.; Fortun-Lamothe, L.; and Huerou-Luron, I. L., 2005. An early stimulation of solid feed intake slightly influences the morphological gut maturation in the rabbit. Reproduction Nutrition Development, 45, 109-122.

Gidenne, T. and Lebas, F. (2006). Feeding Behaviour In Rabbits. In Feeding in domestic vertebrates. From structure to behaviour (ed. V Bels), pp. 179-209. CABI Publishing, Wallingford, UK.

Gidenne, T. and Feugier, A. (2009). Feed restriction strategy in the growing rabbit. 1. Impact on digestion, rate of passage and microbial activity. Animal , 3: 501-508.

Gidenne, T.; Bannelier, C.; Combes, S. and Fortun-Lamothe, L. (2009). Interaction between the energetic feed concentration and the restriction strategy - impact on feeding behaviour, growth and health of the rabbit. 13e 'me Journe' es de Recherches Cunicoles, Le Mans, France, 63-66.

Isolauri, E.; Sutas, Y. and Kankaanpaa, P. (2001). Probiotics: effects on immunity. Am. J. Clin. Nutr., 73:444-50.

Je'rome N.; Mousset, J. L.; Messager, B.; Deglaire, I.; and Marie P., 1998. Influence de diffe' rentes me' thodes de rationnement sur les performances de croissance et d'abattage du lapin. In A7e 'mes Journe' es de Recherches Cunicoles (ed. JM Perez), pp. 175-178. ITAVI Publishing, Paris, Lyon.

Kritas, S.K. ; Petridou, E.; Fortomaris, P.; Tzika, E.; Arsenos, G.; and Koptopoulos, G.(2008). Effect of inclusion of probiotics on microorganisms content, health and performance of fattening rabbits: 1 . Study in a commercial farm with intermediate health status. $9^{\text {th }}$ World Rabbit Congress - June 10-13, 2008 - Verona - Italy

Lye, H.S.; Rusul, G. and Liong, M.T. (2010). Mechanisms of Cholesterol Removal by Lactoballi Under Conditions That Mimic the Human Gastrointestinal Tract. International Dairy Journal; 20(3)169-175.

Miettinen. M.; Vuopio-Varkila. J. and Varkila, K. (1996). Production of human tumor necrosis factor alpha, interleukin-6, and interleukin-10 is induced by lactic acid bacteria. Infect Immun., 64:5403-5405.

Maiorova, A.S. (2007). Vliyanie Probiotikov s Antitoksicheskoi Aktivnost'yu na produktivnost' Krolikov, Avtoref. Dis. Kand. Biol. Nauk, Rodniki: NII Pushnogo Zverovodstva I Krolikovodstva, Vol. 24.

North, M.O. (1981). Commercial Chicken Production. Annual $2^{\text {nd }}$ Edition, Production $6^{\text {th }}$ ED. Intestate Printers and Publishers. INC., USA. 
NRC, (1977). Nutrient Requirements Of Rabbits. National Academic if Science, Washington DC, USA.

Oso, A.O.; Idowu, O. M. O.; Haastrup, A. S.; Ajibade, A. J.; Olowonefa, K. O.; Aluko, A. O.; Ogunade, L. M., Osho, S. O.; and Barngbose A. M. (2013). Growth performance, apparent nutrient digestibility, caecal fermentation, ileal morphology and caecal microflora of growing rabbits fed diets containing probiotics and prebiotics. Livestock Science, 157, 184-190.

Özkan, C.; Kaya, A. and Akgül, Y.(2012). Normal values of haematological and some biochemical parameters in serum and urine of New Zealand White rabbits. World Rabbit Sci. 2012, 20: 253 - 259

Pogány Simonová1, M.; Lauková1, A.; Žitňan, R.; and Chrastinová, L., (2015). Effect of rabbit-origin enterocin-producing probiotic strain Enterococcus faecium CCM7420 application on growth performance and gut morphometry in rabbits. Czech J. Anim. Sci., 60 (11): 509-512.

Salminen, S.; Bouley, C.; Boutron-Ruault, M.-C.; Cummings, J.H.; Franck, A.; Gibson, G.F.R.; Isolauri, E.; Moreau, M.-C.; Roberfroid, M. and Rowland, I. (1998). Functional food science and gastrointestinal physiologyand function. Brit. J. Nutr. 80 (suppl. 1): S147-S171.

Sherman, P.M.,Ossa,J.C.Johnson-Henry,K.(2009). Unravelling mechanisms of action of probiotics.Nutr.Clin.Pract.21,10-14.

Snedecor, G.W. and Cochran, W.G. (1982). Statistical Methods. 7th Edition, Iowa State University Press, Towa, 511.

Tumova, E.; Skrivan, M.; Skrivanova, V.; and Kacorovsk, L., (2002). Effect of early feed restriction on growth in Broiler chickens, turkeys and rabbits. Czech J. Anim. Sci. 47:418-428.

Tumova, E.; Zita, L.; Skrivanova, V.; Fucikova, A.; Skrivan. M. and Buresova, M. (2007). Digestibility of nutrients, organ development and blood picture in restricted and ad libitum fed broiler rabbits. Archiv Fur Geflu"gelkunde 71, 6-12.

Van Harten, S. and Cardoso, L.A. (2010). Feed restriction and genetic selection on the expression and activity of metabolism regulatory enzymes in rabbits. Animal , 4: 1873-1883.

Villamide M.J; Maertens, L.; and De Blas, J. C., 2010. Feed Evaluation. In: The Nutrition of the Rabbit. (Edit. De Blas J. C. and Wiseman J.), 2nd Ed. CABI, Wallingford, pp. 151-162.

Vesterlund, S.; Karp, M. and Salminen S. (2006). Staphylococcus aureus adheres to human intestinal mucus but can be displaced by certain lactic acid bacteria. Microbiology;152:1819-26. 
Wang, Z.; Gu, Z.; Huo, Y.; Chen, B.; Liu, Y; Zhao, Z. and Zhang, G. (2008). Effects of probiotics and nanometer implement on growth performance of rex rabbit. $9^{\text {th }}$ World rabbits Congress-June 10-13, Verona-Italy, 837-840.

Yakubu, A.; Salako, A.E.; Ladokun. A.O.; Adua. M.M. and Bature T.U.K. (2007). Effects of feed restriction on performance, carcass yield, relative organ weights and some linear body measurements of weaner rabbits. Pakistan Journal of Nutrition, 6: 391-396.

Xiccato, G and Trocino, A. (2010). Energy And Protein Metabolism And Requirements. In: De Blass, C. and Wiseman, J. (Eds.) The Nutrition of the rabbit ( $2^{\text {nd }}$ Edition). CABI publishing. Wallingford, UK (in press).

\section{تأثير التغذية المبكرة علي عليقة مضاف اليها منتج بكتريا داعمة للحيوية

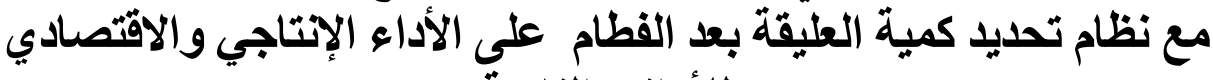 لملأرانب النامية}

$$
\begin{aligned}
& \text { ملاك منصور بشاره، احمد منير العزب، هاني نبيل فهيم، عادل السيد الاسوقي، مني }
\end{aligned}
$$

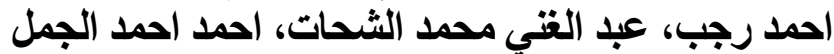

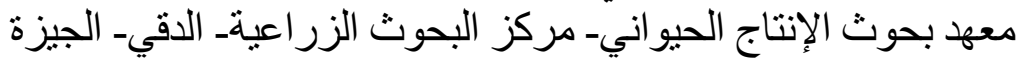

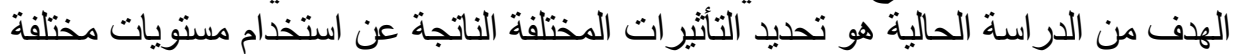

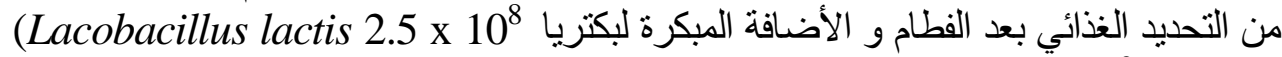
CFU/g, Bacillus subtilis 1.8 x 109 CFU/g)

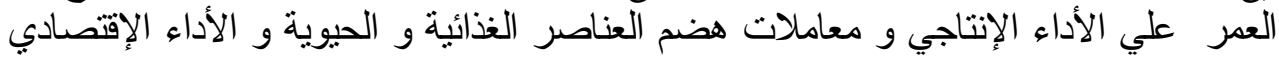

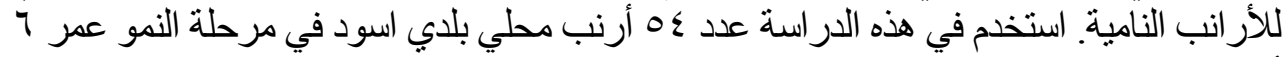

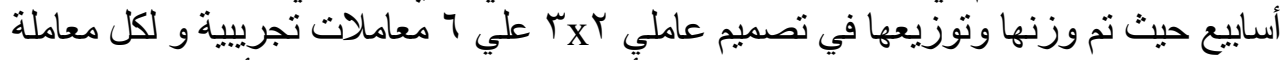

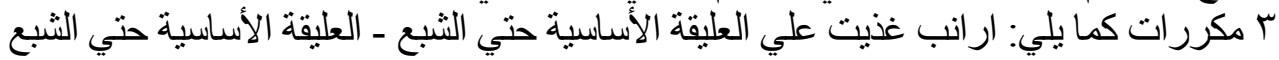

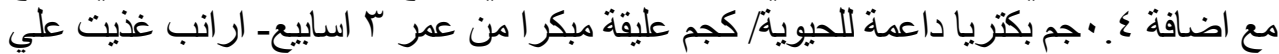

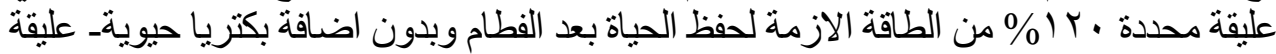

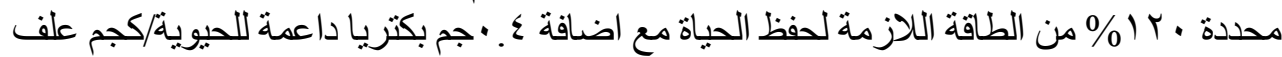

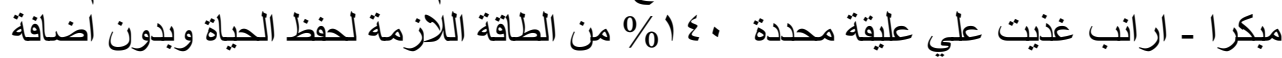

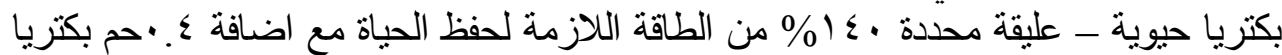

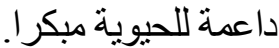
اوضحت النتائج ان التغذية علي عليقة بها البكتريا الداعمه للحيوبة من عمر ب أساييع قبل

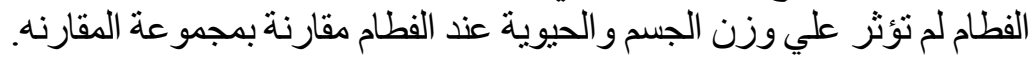


بعد الفطام وجد ان الأرانب النامية المغذاه علي العليقة حتي الثنبع والمضاف اليها البكتريا

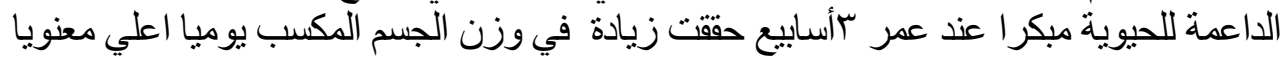

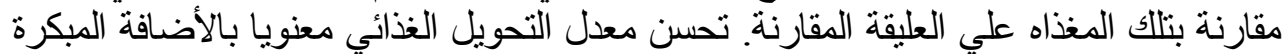

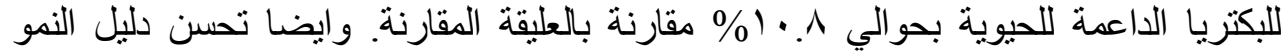
بإضافة البكتريا الحيوية الي العليقة. حققت الأر انب المغذاه علي العليقة حتي الثبع أعلي وزن جسم مكتسب يومي مقارنة بنظم

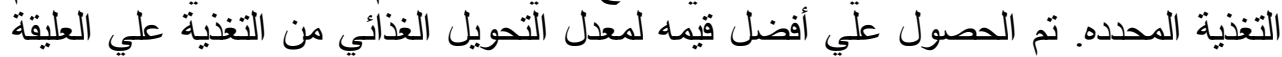

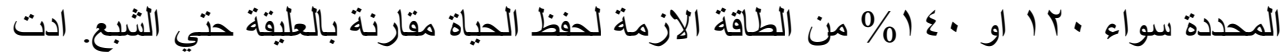

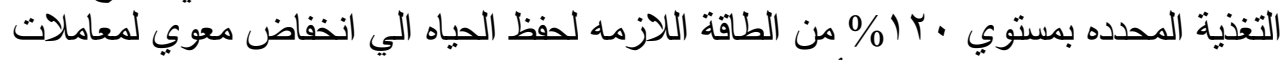

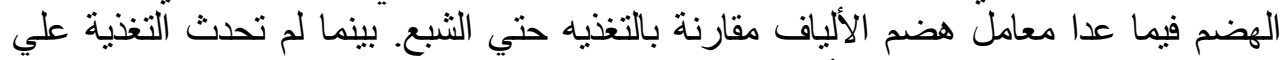

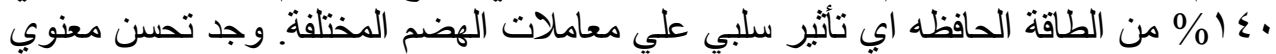

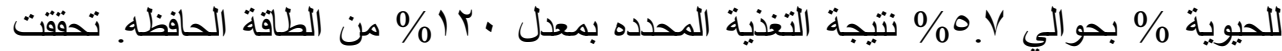

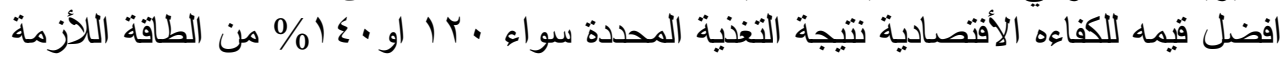

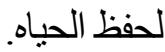

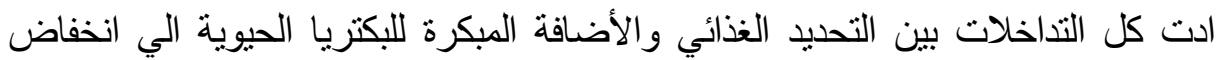

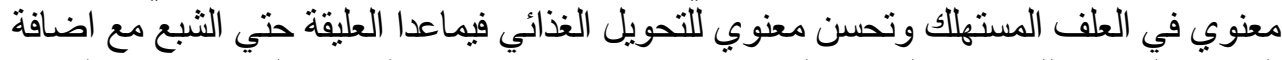

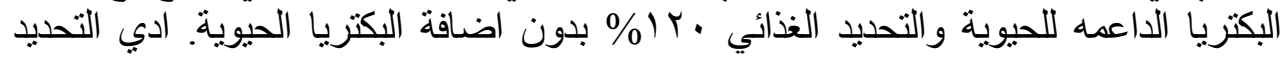

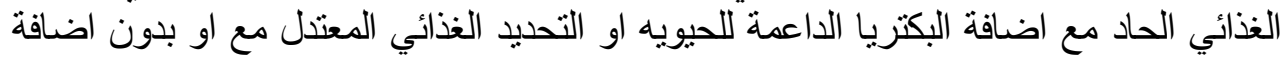

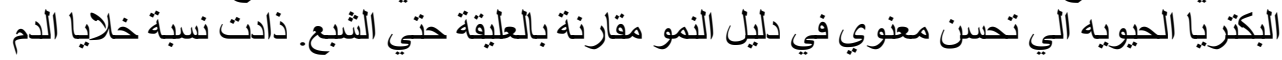

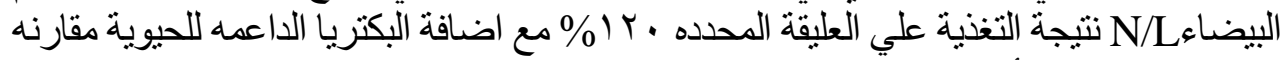

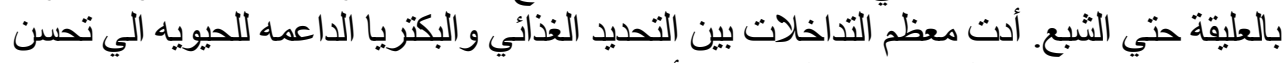

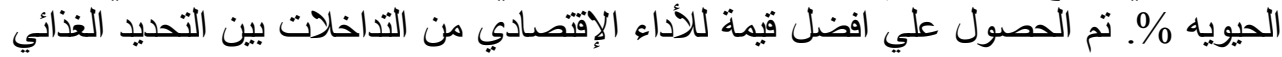
و البكتريا الحيوية فيما عدا التخذية حتي الثبع مع اضافة البكتريا الحيوية مقارنة بالعليقة حتي لإني

اوضحت نتائج التجربة الحالية الأرانب النامية التي بدأت تتغذبي مبكر ا علي عليقة مضاف اليها

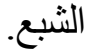
بكتيريا داعمه للحيويه ابتداءا من عمر الي بـح استاييع قبل الفطام مع استمرار اضافة البكتريا

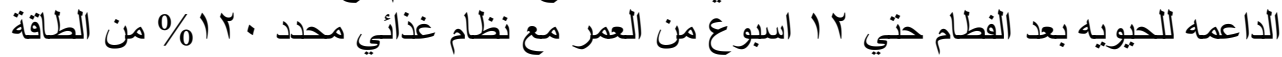

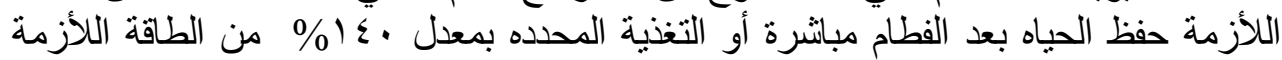

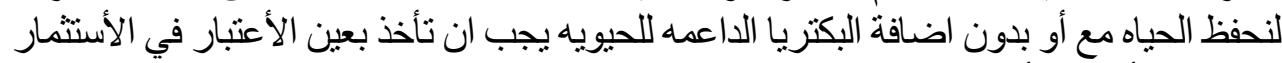

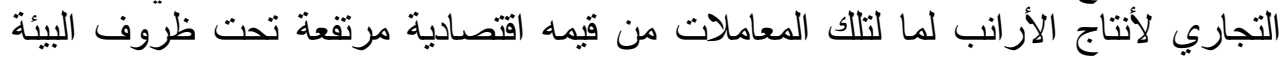

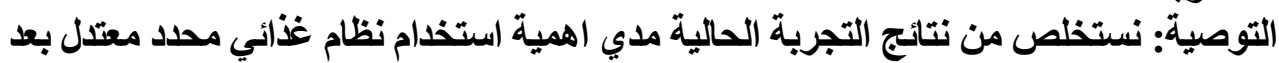

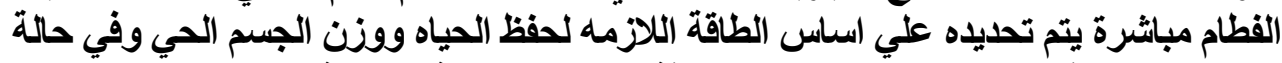

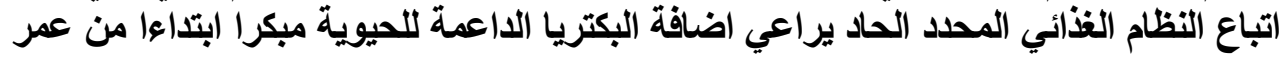
ابايوم وذلك للحصول علي افضل اداء أنتاجي واقتصادي. 